\title{
Molecular Diagnostics of Medically Important Bacterial Infections
}

\author{
Beverley Cherie Millar ${ }^{1}$, Jiru $\mathrm{Xu}^{2}$, and John \\ Edmund Moore ${ }^{1 *}$
}

${ }^{1}$ Northern Ireland Public Health Laboratory, Department of Bacteriology, Belfast City Hospital, Belfast, Northern Ireland, BT9 7AD, UK

${ }^{2}$ Northern Ireland Public Health Laboratory, Department of Bacteriology, Belfast City Hospital, Belfast, Northern Ireland, BT9 7AD, UK, and Department of Pathogenic Biology, Xian-Jiatong University, Xi'an, The People's Republic of China

\begin{abstract}
Infectious diseases are common diseases all over the world. A recent World Health Organization report indicated that infectious diseases are now the world's biggest killer of children and young adults. Infectious diseases in non-industrialized countries caused $45 \%$ in all and $63 \%$ of death in early childhood. is by. In developed countries, the emergence of new, rare or already-forgotten infectious diseases, such as HIVIAIDS, Lyme disease and tuberculosis, has stimulated public interest and inspired commitments to surveillance and control. Recently, it is reported that infectious diseases are responsible for more than 17 million deaths worldwide each year, most of which are associated with bacterial infections. Hence, the control of infectious diseases control is still an important task in the world. The ability to control such bacterial infections is largely dependent on the ability to detect these aetiological agents in the clinical microbiology laboratory.

Diagnostic medical bacteriology consists of two main components namely identification and typing. Molecular biology has the potential to revolutionise the way in which diagnostic tests are delivered in order to optimise care of the infected patient, whether they occur in hospital or in the community. Since the discovery of PCR in the late 1980s, there has been an enormous amount of research performed which has enabled the introduction of molecular tests to several areas of routine clinical microbiology. Molecular biology techniques continue to evolve rapidly, so it has been problematic for many laboratories to decide upon which test to introduce before that technology becomes outdated. However the vast majority of diagnostic clinical bacteriology laboratories do not currently employ any form of molecular diagnostics but the use such technology is becoming more widespread in both specialized regional laboratories as well as in national reference laboratories. Presently molecular biology offers a wide repertoire of techniques and permutations of these analytical tools, hence this article wishes to explore the application of these in the diagnostic laboratory setting.
\end{abstract}

\section{Introduction}

The last ten years of the twentieth century allowed for an exponential increase in the knowledge of techniques in molecular biology, following the cellular and protein era of the 1970s and 1980s. This explosion of technologies from the primary discipline of molecular biology has had major consequences and has allowed for significant developments in many areas of the life sciences, including bacteriology. Molecular bacteriologists are now beginning to adopt general molecular biology techniques to support their particular area of interest. This chapter aims to examine the current situation with regard to the application of molecular biology techniques in the area of medical bacteriology, and is primarily concerned with the molecular identification of causal agents of bacterial infections. The chapter also aims at giving a broad overview of the application of current technology so that the reader has a more comprehensive overview of the diversity of techniques that are available, either as research tools or which may be used in a routine setting. The requirements of adopting molecular diagnostics in terms of management, cost, labour and space will be discussed. This chapter is a presentation of the development and the current knowledge, literature, and recommendation about the laboratory diagnosis of infectious diseases. The focus of this review is on medically important bacterial infections. The overall aim of this chapter is to provide an appreciation of the role molecular diagnostics has in routine clinical microbiology and how best these techniques can be integrated in order to enhance the healthcare system.

\section{Historical perspective}

In 1676, Anton van Leeuwenhoek, a Dutch cloth merchant and amateur lens grinder, first observed living microorganisms using his simple microscope, which he called "animalcules". He examined "animalcules" in the environment, including pond water, sick people and even his own mouth and found that these "animalcules" existed everywhere. He described and recorded all the major kinds of microorganisms: protozoa, algae, yeast, fungi, and bacteria in spherical, rod, and spiral forms. His discoveries opened up a new world namely the microbial world and this was the first milestone in the history of diagnostic microbiology.

Although the suggestion that disease was caused by invisible living creatures was made by the Roman physician Girolamo Fracastoro in 1546, people did not clearly recognize the role of microorganisms in diseases, until 1876, after 200 years that Leeuwenhoek found his little "animalcules", the German physician, Robert Koch established his famous "Koch's postulates" according to the relationship between Bacillus anthracis and anthrax. Koch's postulates include:

*For correspondence: jemoore@niphl.dnet.co.uk 
a. In order to prove that a certain microbe is the cause of a certain disease, that same microbe must be found present in all cases of the disease.

b. This microbe must then be completely separated from the diseased body and grown outside that body in a pure culture.

c. This pure culture must be capable of gibing the disease to healthy animals by inoculating them with it.

d. The same microbe should then be obtained from the animals so inoculated, and then grown again in a pure culture outside the body.

Koch was a great pioneer in medical microbiology and his postulates are still considered fundamental to bacteriology even today. Communicable diseases can occur in populations and cause epidemics or even pandemic problems. Some outbreak diseases are so serious that they can cause hundreds, thousands, even millions of deaths, in epidemic or pandemic proportions. For example, bubonic plague, caused by Yersinia pestis, originally spread from Asia and was carried by rat-fleas via the ports of the Black Sea to Europe, which caused 42 million deaths, 25 million in Europe, in just less than five years between 1347 and 1352, reducing the population of Europe to 50 million. The scourge of tuberculosis was about to appear. Bunyon's epithet, "The Captain of the Men of Death", tells of the overwhelming fear that the disease was associated with, even until today. Until the present era, it was recognized and feared as one of the most common and most serious hazards of life, one from which escape was almost impossible. At the same time, the well-known Renaissance physician, Jean François Fernel was performing some early and important studies on the circulatory system. In Fernel's book Medicini, he describes descriptions of several pathological conditions, including what is now believed to be some of the earliest published accounts of endocarditis.

Comparing conventional detection methods of which have been developing over a century, molecular detection methods are relatively very young, with a history of approximately no more than 20 years old. Although deoxyribonucleic acid, or DNA, was discovered in the late $1860 \mathrm{~s}$, it was not used until the restriction enzyme and the recombinant DNA techniques were discovered in the 1970s. During this time, many scientists worked diligently to find the profound mystery of DNA. To trace the development of molecular detection methods, we should remember some pioneers and their discoveries.

In 1869, Johann Friedrich Miescher, a Swiss physician, discovered a weakly acidic substance of unknown function in the nuclei of human white blood cells, this substance, which was later named, deoxyribonucleic acid, or DNA. The substance was largely ignored for nearly a century because it seemed too simple to serve any significant purpose. This view changed dramatically in 1949, when Erwin Chargaff, a biochemist, reported that DNA composition was species specific; that is, that the amount of DNA and its nitrogenous bases varied from one species to another. In addition, Chargaff founds that the amount of adenine equalled the amount of thymine, and the amount of guanine equalled the amount of cytosine in DNA, from every species. During this time scientists discovered that chromosomes, which were known to carry hereditary information, consisted of DNA and proteins. In 1928, Franklin Griffith, a British medical officer, discovered that genetic information could be transferred from heat-killed bacteria cells to viable organisms. This phenomenon, called transformation, provided the first evidence that the genetic material is a heat-stable chemical. In 1944, Oswald Avery, a Canadian physician and bacteriologist, and his colleagues McCarty and Colin MacLeod, identified Griffith's transforming agent as DNA. Experiments conducted throughout the 1940s showed that DNA actually seemed to be the genetic material. However, it was still not known what the structure of DNA was, and how such a molecule could contain all the information needed to produce a human being or other living organisms, until 1953, when James Watson and Francis Crick discovered the molecular structure of DNA. After building successive scale models of possible DNA structures, they deduced that it must take the twistedladder shape of a double helix. The sides of the ladder consist of a "backbone" of sugar and phosphate molecules. The nitrogen-rich bases, A, T, G and C, form the "rungs" of the ladder on the inside of the helix. The pair discovered that base A would only pair with T, while G would only pair with $\mathrm{C}$. They were awarded the Nobel Prize in Physiology or Medicine in 1962 for their discovery, shared with Maurice Wilkins, whose work with Rosalind Franklin on Xray crystallography had provided further crucial evidence. In 1961, François Jacob and Jacques Monod develop a theory of genetic regulatory mechanisms, showing how, on a molecular level, certain genes are activated and suppressed and they were awarded the Nobel Prize in Physiology or Medicine in 1962 for their contribution. In 1961 Marshall Nirenberg, a young biochemist at the National Institute of Arthritic and Metabolic Diseases, discovered the first "triplet"-a sequence of three bases of DNA that codes for one of the twenty amino acids that serve as the building blocks of proteins. Subsequently, within five years, the entire genetic code was deciphered. At end of 1960s, almost all about the DNA structures and functions were understood in theory, but people still could not get any gene as they wanted or change any gene as they needed until 1970s when some in important enzymes were discovered. In 1970, Hamilton Smith, an American microbiologist, isolated the first restriction enzyme, an enzyme that cuts DNA at a very specific nucleotide sequence. Over the next few years, several more restriction enzymes were isolated. He shared the Nobel Prize in Physiology or Medicine with Werner Arber and Daniel Nathans in 1978 for his discovery. In 1972, Paul Berg assembled the first DNA molecules that combined genes from different organisms. Results of his experiments represented crucial steps in the subsequent development of recombinant genetic engineering. In 1980, Paul Berg shared the Nobel Prize in Chemistry with Walter Gilbert and Frederick Sanger, for "his fundamental studies of the biochemistry of nucleic acids, with particular regard to recombinant DNA." In 1973, Stanley Cohen and Herbert Boyer combined their efforts to create the 
construction of functional organisms that combined and replicated genetic information from different species. Their experiments dramatically demonstrated the potential impact of DNA recombinant engineering on medicine and pharmacology, industry and agriculture. Walter Gilbert (with graduate student Allan M. Maxam) and Frederick Sanger, in 1977, working separately in the United States and England, developed new techniques for rapid DNA sequencing. The methods devised by Sanger and Gilbert made it possible to read the nucleotide sequence for entire genes, which run from 1,000 to 30,000 bases long. For discovering these techniques Gilbert and Sanger received the Albert Lasker Medical Research Award in 1979, and shared the Nobel Prize in Chemistry in 1980 (Genome News Network, http://www.genomenewsnetwork.org). In the 1970s, nucleic acid hybridization methods were mostly used methods and DNA probes were the powerful tools in molecular biology, microbiology, virology, genetics, and forensics etc. Although hybridization methods are highly specific for detecting targets, they are limited by their sensitivity. To get more sensitive and specific methods, Kary Mullis conceived and helped develop polymerase chain reaction (PCR), a technology for rapidly multiplying fragments of DNA in 1983 and he was awarded the Nobel Prize in Chemistry in 1993 for this achievement. In 1985, Saiki and his colleagues first used the new method to detect patient's $\beta$-globin gene for diagnosis of sickle anaemia. In 1987, Kwok and colleagues identified human immunodeficiency virus (HIV) by using PCR method and this was the first report the application of PCR in clinical diagnosis infectious disease.

Over the past 20 years, molecular techniques have been developed very broadly and fast. The nucleic acid amplification technology has been opened a new century for microbial detection and identification. At present, molecular detection methods, especially PCRbased methods, have become more and more important detection methods in the clinical diagnosis laboratory setting.

\section{Applications of molecular diagnostic identification} Molecular identification should be considered in three scenarios, namely (a) for the identification of an organism already isolated in pure culture, (b) for the rapid identification of an organism in a diagnostic setting from clinical specimens or (c) for the identification of an organism from non-culturable specimens, e.g. culturenegative endocarditis.

\section{Difficult to identify organisms}

Most modern clinical microbiology diagnostic laboratories rely on a combination of colonial morphology, physiology and biochemical/serological markers, for their successful identification either to the genus level or more frequently to the species level. It is important that organisms are correctly identified for a number of reasons, including the correct epidemiological reporting of causal agents in a given disease state, as well as for infection control purposes. Sometimes it is argued that physicians may simply accept the Gram result and corresponding antibiogram in order to determine the optimum management plan of an infected patient. This lack of identification ability requires caution, for the two reasons stated above. Consequently, there is a need to reliably identify organisms of clinical significance in a cost effective and timely manner. Most laboratories today rely on identification through biochemical profiling with the API-identification schema, as well as with the BBL-Crystal system, although there are several additional phenotypic systems, which are commercially available. Employment of one or a combination of such phenotypic schemes offers the diagnostic microbiologist a result in virtually all clinical situations, however, there is a small number of organisms where such methods are unable to give a reliable identification, e.g., the non-fermenting Gram-negative rods.

\section{Rapid identification from clinical specimens}

Traditional culture may take several days to allow sufficient growth of an organism so that a positive identification may be subsequently made. Often in clinical microbiology, such allowances in time result in patients being managed empirically, until the culture result is known, which may allow for the sub-optimal management of some patients. However, there is a role for molecular identification techniques from clinical specimens where a culture would give you a comparable result, but several days later. Hence, there is a role for such techniques in outbreak settings, as well as in today's world of potential bioterrorist attack.

\section{Identification from culture-negative specimens}

Since its origins in the late $19^{\text {th }}$ century, bacteriology has largely been based on the ability to culture organisms of interest usually under in vitro laboratory conditions. The forefathers of bacteriology including Pasteur and Koch were ardent exponents of bacteriological culture and the affinity between the bacteriologist and laboratory culture has remained strong for the past 100 years. Indeed, it may be argued that the historical success of bacteriology has been a direct result of bacteriological culture, as well as its widespread adoption throughout the world. Today the ability to culture bacteria in vitro remains the cornerstone of this discipline. However, there are several situations where molecular approaches should be considered where conventional culture fails to identify the causal organism due to one or more of the following reasons including (i) prior antibiotic therapy, e.g. treatment of acute meningitis with i.v. benzylpenicillin, (ii) where the organism is fastidious in nature, such as the HACEK group of organisms in the case of endocarditis, (iii) where the organism is slow growing, e.g. Mycobacterium spp., (iv) where specialized cell culture techniques are required, e.g. Chlamydia spp. and Coxiella burnetti.

Molecular methods may be included in the diagnostic laboratory's diagnostic algorithm, thus enabling laboratories to make a rapid and reliable identification. Several molecular approaches may be adopted to help with the identification.

\section{Description of molecular techniques employed in medical microbiology}

Nucleic acid hybridization is based on the ability of two single nucleic acid strands that have complementary base sequences to specifically bond with each other and form 
a double-stranded molecule, or duplex or hybrid. The single-stranded molecules can be RNA or DNA, and the resultant hybrids formed can be DNA-DNA, RNA-RNA, or DNA-RNA. Hybridization assays require that one nucleic acid strand (the probe) originates from an organism of known identity and the other strand (the target) originates from an unknown organism to be detected or identified. The probes are capable of identifying organisms at, above, and below the species level. Hybridization reactions can be done using either a solution format or solid support format. The solid support formats include: filter hybidizations, sandwich hybridizations, and in situ hybridizations. Nucleic acid hybridization methods were developed in the 1970s, and they are still used in microbial detection and identification today. They are also the important detection tools in real-time PCR such as TaqMan and LightCycler platforms.

\section{Polymerase chain reaction (PCR)}

\section{Principle of PCR}

Polymerase Chain Reaction (PCR) is an enzyme-driven, primer-mediated, temperature-dependent process for replicating a specific DNA sequence in vitro. The principle of PCR is based on the repetitive cycling of three simple reactions, the conditions of which vary only in the temperature of incubation. The three simple reactions include:

1. Denaturing: When the temperature is raised to around $95^{\circ} \mathrm{C}$, template DNA double strand is separated to two single strands.

2. Annealing: When the temperature reduces to approx. $55^{\circ} \mathrm{C}$, two specific oligonucleotide primers bind to the DNA template complementarily.

3. Extension: When the temperature rises to $72^{\circ} \mathrm{C}$, DNA polymerase extends the primers at the 3 ' terminus of each primer and synthesizes the complementary strands along 5'to 3' terminus of each template DNA using desoxynucleotides containing in media. After extension, two single template DNA strands and two synthesized complementary DNA strands combine together forming two new double strand DNA copies. After extension, the reaction will repeat above steps. Each copy of DNA may then serve as another template for further amplification. PCR products will be doubled in each cycle. After $n$ cycles (approx. 30), the final PCR products will have $2^{\mathrm{n}}$ copies of template DNA in theory and it just needs few hours.

\section{Specific PCR}

Specific PCR is the simplest PCR approach of which is designed for detecting specific target microbes. In specific PCR, primers are designed complimentary to a known DNA target and specific for the microbe being assayed. This is a key point for specific PCR so that the primers should be so-designed so that they are strictly specific for the targeted microorganisms. As the result is specific for the detection of target microbes, this method can be used as a direct detection and identification method. This is the most widely used method in the diagnosis of infectious diseases. Many organisms, such as Mycobacterium tuberculosis, pneumococci, meningococci and Burkholderia cenocepacia, can be identified by specific PCR directly.

\section{Multiplex PCR}

In multiplex PCR, two or more primer pairs are included in one reaction tube and two or more DNA templates are targeted simultaneously. This is a relatively simple molecular way to detect few different bacteria in one PCR reaction. In multiplex PCR, the primer pairs should be specific to the target gene and the PCR products should be in different sizes.

\section{Nested/semi-nested PCR}

In this approach, genomic template DNA is amplified with two sets of primers. The first PCR set produces a larger PCR product than that in second PCR set. The second PCR set uses the first PCR product as template DNA to amplify an internal region of DNA during the second (nested/semi-nested) amplification stage. The primers in the second PCR set can be different to the first set (nested) or one of the primers can be the same as the first set (semi-nested). This method can be used to increase the sensitivity of detection or to identify the first set PCR products when the primers in the second $P C R$ reaction are species-specific.

\section{Broad range $P C R$}

Broad range PCR is a very useful approach for detecting microbes universally. The primers in broad range PCR are selected from the conserved regions of a particular gene that is shared by a given taxonomic group. This crucial important for broad range PCR to select real broad range primes. As the 16S rRNA gene is found in all bacteria and contains certain conserved regions of sequence, it has been mostly used as the broad range PCR target gene for detecting bacteria. The 23S rRNA is similar with the 16S rRNA gene and it may also be used to a lesser extent, as the broad range PCR target gene. Given that, there is relatively limited information regarding the 23S rRNA gene, this gene locus gene is not so popular, in comparison with the 16S rRNA gene. Another region of the rRNA machinery that is used in broad range PCR is the inter-spacer (ITS) region between $16 \mathrm{~S}$ and $23 \mathrm{~S}$ rRNA genes. In this broad range PCR approach, the forward primer is from 16S rRNA gene, and the rewords primer is form 23S rRNA gene. An example of the arrangement of the rRNA operons is illustrated with the obligate Gram +ve intracellular pathogen, Tropheryma whipplei.

1. Nested PCR: After broad range DNA amplification, species-specific primers are used in tandem with a second set of DNA amplification primers. The result can be detected by standard gel electrophoresis.

2. DNA probe hybridization: The broad range PCR products can be identified by using species-specific DNA probe hybridization. The probe and the PCR products are incubated together in a single test tube, and the binding of probe to the target is measured.

3 DNA enzyme immunoassay (DEIA): In this method, 
an anti-dsDNA antibody, particularly recognizes the hybridization product, resulting from the reaction between target DNA and a DNA probe. The final product is revealed by means of a colorimetric reaction. The DEIA increases the sensitivity of a previous PCR by including enzymatic reactions. The hybridization between specific probe and PCRamplified target DNA, as well as the formation of target DNA/probe hybrids and anti-dsDNA antibody complex, also enhances the specificity.

4. Single-strand conformation polymorphism (PCRSSCP): SSCP generally is used as a microbe typing and mutation detection method. It can also be used for the purposes of microbe identification. After PCR products are denatured to two single-stranded DNAs, the physical conformational changes in singlestranded DNA are based on the physiochemical properties of the nucleotide sequence. Conventionally, the variations in the physical conformation are detected with non-denaturing polyacrylamide gel electrophoresis and stained with silver. Also, the result can be detected by using fluorescencelabelled primers and analysed on an automated DNA sequencer,

5. Restriction endonuclease digestions (PCR-RFLP): After restriction endonuclease digestions, the amplified DNA fragments are cut to different small fragments according to their DNA sequences. The resulting fragments can be separated by gel electrophoresis, and/or then transferred to a nylon membrane. RFLP usually is used as a microbe typing and epidemiological investigative method.

\section{Reverse transcription-polymerase chain reaction}

\section{(RT-PCR)}

RT-PCR is the technique of synthesis of cDNA from RNA by reverse transcription (RT) firstly, which is then followed with amplification of a specific cDNA by PCR. This is the most useful and sensitive technique for mRNA detection and quantitation that is currently available. RT-PCR is mostly used to detect viruses and the viability of microbial cells through examination of microbial mRNA.

\section{Real-time PCR}

In 1993, Higuchi first described a simple, quantitative assay for any amplifiable DNA sequence. This method is based on using fluorescent labelled probes to detect, confirm, and quantify the PCR products as they are being generated in real time. In recent years, some commercial automated real-time PCR systems have been available (LightCycler \& TaqMan). In these systems, such as the LightCycler $^{\mathrm{TM}}$ and the SmartCycler $\AA$, these systems perform the real-time fluorescence monitoring by using fluorescent dyes such as SYBR-Green I, which binds non-specifically to double-stranded DNA generated during the PCR amplification. Others, such as the TaqMan, use florescent probes that bind specifically to amplification target sequences. At present, some broad range primers and probes targeting the 16S rRNA gene have been developed in these systems to detect and identify bacteria universally. The real-time PCR systems not only reduce the detection time (results can be ready in less than on hour), but also can reduce contamination risks because amplification and detection occur within a closed system.

\section{DNA sequencing}

In 1977, two different methods for sequencing DNA were developed, namely, the chain termination method and the chemical degradation method. Both methods were equally popular to begin with, but, the chain termination method soon become more popular and this method is more commonly used today. This method is based on the principle that single-stranded DNA molecules that differ in length by just a single nucleotide can be separated from one another using polyacrylamide gel electrophoresis. The fixed laser beam excites the fluorescently labelled DNA bands and the light emitted is detected by sensitive photodetectors. DNA sequence data is the most accurate and definitive way to identify microbes because the microbes may be identified by base pair to base pair of the nucleic acid. The DNA sequences of the variable regions form the basis of phylogenetic classification of microbes. By sequencing broad range PCR products, it is possible to detect DNA from almost any bacterial species. After comparing the resulting sequences with known sequences in GenBank or other databases, the identity of the unknown bacteria can be revealed. Since the 1990s, 16S rDNA sequencing has become a powerful tool, which is used more and more in microbial detection and identification algorithms, especially for unusual, non-culturable, fastidious and slow growing pathogens, or after antibiotics that have been administered to the patient. Such a technique as this is becoming a routine method of detection and identification of bacteria, thus overall helping to combat infectious diseases.

\section{Gene targets}

Unlike diagnostic virology of which targets DNA as well as RNA, traditionally the majority of diagnostic assays in medical bacteriology have been based around the amplification of DNA in a target gene, as opposed to $m R N A$ or other nucleic acid signal. This may be performed as DNA is an extremely stable molecule (Farkas et al., 1996), as opposed to mRNA which has a short half-life (Carpousis, 2002; Steege, 2000). Generally molecular diagnostics in clinical bacteriology is not concerned with regard to the viable status of a organism being detected, but is concerned with the qualitative detection of an organism in a symptomatic patient with the relative clinical presentation, e.g., the detection of meningococcal DNA in the cerebral spinal fluid of a paediatric patient with suspected meningitis. The scenario is completely different where medical bacteriology interfaces with food/public health microbiology, where simple qualitative detection of DNA from pathogenic foodborne bacteria is insufficient or can indeed be misleading and where other more defined molecular viability assays are required, e.g. the molecular detection of viable versus non-viable Salmonella sp. in a sample of dried milk powder suspected of causing food-poisoning. In this case, it is insufficient to simply detect the presence/absence of Salmonella DNA from an extract of the milk powder as a false positive may be detected under these circumstances, but which in reality represents archival DNA from dead cells killed during the 
drying process. Therefore it is important to give careful consideration to what one wishes to achieve from a molecular assay and thus careful emphasis must be placed on the target gene locus.

\section{Universal gene targets}

\section{Ribosomal RNA}

Where there is no indication regarding the identity of a bacterial organism, employment of amplification of DNA encoding ribosomal RNA genes in conjunction with DNA sequencing of the amplicon has proven to be valuable (Patel, 2001; Kolbert and Persing, 1999). In bacteria, there are three genes which make up the rRNA functionality, i.e. $5 S, 16 S$ and $23 S$ rRNA. The 16 S rRNA gene has historically been most commonly employed for identification purposes (see Table 1), due to it being highly conserved and having a moderate copy number depending on the genus. 16S rRNA genes are found in all bacteria and accumulate mutations at a slow, constant rate over time, hence they may be used as "molecular clocks" (Woese, 1987). Highly variable portions of the $16 S$ rRNA sequence provide unique signatures to any bacterium and useful information about relationships between them. Since 16S rRNA molecules have crucial structural constraints, certain conserved regions of sequence are found in all known bacteria. "Broad-range" PCR primers may then be designed to recognize these conserved bacterial $16 \mathrm{~S}$ rRNA gene sequences and used to amplify intervening, variable or diagnostic regions, without the need to know any prior sequence or phylogenetic information about the unknown bacterial isolate.

More recently, employment of the 16S-23S rRNA intergenic spacer region has become popular due to its high copy number and more importantly its high sequence variability (Gurtler and Stanisich 1996; Shang et al., 2003). Primers are directed to highly conserved regions of the $16 \mathrm{~S}$ and $23 \mathrm{~S}$ rRNA genes and these may either be universal or specific, targeting a specific genus e.g., Bartonella spp. (Houpikian and Raoult, 2001), Chlamydia spp. (Madico et al., 2000), Tropheryma whipplei (Geissdorfer et al., 2001), Mycobacterium spp. (Roth et al., 2000) and Salmonella spp. (Bakshi et al., 2002).

Recently, there have been several reports of employment of the large subunit (23S rRNA) which have been used to identify bacterial species. Anthony et al. (Anthony et al. 2000) reported that the 23S rRNA locus shows more variation between species of medical importance than the 16S rRNA locus. In their study, these workers designed universal 23S rRNA primers which allowed them to detect bacterial agents from 158 positive blood cultures which were identified using a hybridization assay with specific oligonucleotide probes. These workers concluded that the accuracy, range and discrimatory power of their assay could be continually extended by adding further oligonuclotides to their panel without significantly increasing complexity and cost. Furthermore, the 23S rRNA gene locus has been used specifically in order to detect Stenotrophomonas maltophila from patients with cystic fibrosis (Whitby et al., 2000).

\begin{tabular}{|c|c|c|}
\hline Infection & Clinical specimen & \\
\hline Bacterial endophthalmitis & Vitreous fluid (VF) and aqueous humour ( $\mathrm{AH}$ ) specimens & Therese et al. (1998) \\
\hline Bloodborne sepsis & Blood-EDTA & Xu et al. (2003) \\
\hline Chronic prosthetic hip infection & & Tunney et al. (1999) \\
\hline Detection of tick infecting bacteria & & Schabereiter-Gurtner et al. (2003) \\
\hline Endocarditis & $\begin{array}{l}\text { Isolate } \\
\text { Heart valve } \\
\text { Blood culture } \\
\text { Blood } \\
\text { Arterio-embolic tissue }\end{array}$ & $\begin{array}{l}\text { Woo et al. (2003) } \\
\text { Moore et al. (2001b); Goldenberger (1997) } \\
\text { Millar et al. (2001) } \\
\text { Hryniewiecki et al. (2002) } \\
\text { Mueller et al. (1999) }\end{array}$ \\
\hline Endodontic infections & & Siqueira et al. (2001) \\
\hline Febrile episodes in leukaemic patients & & Ley et al. (1998) \\
\hline $\begin{array}{l}\text { Helicobacter sp. osteomyelitis in an im- } \\
\text { munocompetent child }\end{array}$ & Biopsy of bone lesion & Harris et al. (2002) \\
\hline Intra-amniotic infection & Amniotic fluid & Jalava et al. (1996) \\
\hline Intra-ocular infection & & Carroll et al. (2000) \\
\hline Maxillary sinus samples from ICU patients & & Westergren et al. (2003) \\
\hline Meningitis & $\begin{array}{l}\text { CSF } \\
\text { Blood-EDTA }\end{array}$ & $\begin{array}{l}\text { Saravolatz et al. (2003) } \\
\text { Xu et al. (2003) }\end{array}$ \\
\hline Nasal polyps. Chronic sinusitis & & Bucholtz et al. (2002) \\
\hline Peritonitis & CAPD fluid from Culture-negative peritonitis & Bailey et al. (2002) \\
\hline Rat bite fever & Blister fluid & Berger et al. (2001) \\
\hline Reactive arthritis & Synovial fluid/tissue & Cuchacovich et al. (2002) \\
\hline Septic arthritis & & Van der Heijden et al. (1999) \\
\hline Wound infection & Wound tissue from venous leg ulcer & Hill et al. (2003) \\
\hline
\end{tabular}


Overall, employment of 16S-23S rRNA and 23S rRNA assays have not been as widely used as those targeting the 16S rRNA gene, probably due to there being relatively limited sequence information available for these gene loci in comparison to the $16 \mathrm{~S}$ rRNA gene, which has been traditionally benefited by there being a formal requirement to describe this rRNA gene in relation to phylogenetic, taxonomic and population genetic studies. Coupled with this, presently the only universal bacterial sequencebased identification scheme available commercially is based on the 16S rRNA gene i.e. the MicroSeq $50016 \mathrm{~S}$ ribosomal DNA (rDNA) bacterial sequencing kit (Applied Biosystems, Foster City, CA) (Patel et al., 2000).

\section{Sequence analysis}

Sequence-based identification methods employing rRNA gene loci require the use of software to allow the identity of the organism to be made. BLASTn and FASTA software tools are commonly employed to make such comparisons between the query sequence and those deposited in global sequence databases, as outlined in Table 2. Interpretative criteria should be used in order to ascertain the identification of the unknown sequence against its most closely related neighbour (Goldenberger et al., 1997).

\section{Heat shock proteins}

Although 16S rRNA may be employed successfully to identify many bacterial species, there are regions within some major genera, in which 16S rRNA gene sequences are not found to be discriminative enough for the identification of certain species, for example, Burkholderia cenocepacia and B. multivorans. In such circumstances, sequences of essential genes other than the 16S rRNA, such as the heat shock proteins (HSP) (HSP60, HSP65, groEL, groER, etc.), have been shown to be useful (Goh et al., 1996; Woo et al., 2002). The heat shock response is an important homeostatic mechanism that enables cells to survive a variety of environmental stresses. A set of heat shock proteins also known as chaperonins are induced when cells are exposed to higher temperatures. This phenomenon has been observed in all organisms, from bacteria and fungi to plants and animals. The chaperonins are a well-characterized, subgroup of molecular chaperones, which includes the GroE subclass. Heat shock proteins appear to be constituents of the cellular machinery of protein folding, degradation and repair (Feltham and Gierasch 2000). This bacterial molecular chaperone plays an important role in normal growth by mediating the folding and/or assembly of different polypeptides, as well as the transport of some secretory proteins across membranes. For the successful reactivation and assembly of some proteins, groEL requires the presence of another heat shock protein, groES and the general properties of the heat shock response in many bacteria have been characterized.

Other "universal" gene loci may also be targeted including the recA locus (Matsui et al., 2001) and the cold shock proteins (Francis and Stewart 1997). However, the major disadvantage of employment of these targets is that there is relatively limited sequence data available for comparison of a query sequence against their respective gene sequence databases. For this reason, these targets are not commonly employed or may be confined to identification purposes within a well-defined population, e.g. the Burkholderia cepacia complex of organisms (Moore et al., 2001a).

\section{Specific targets}

Molecular identification of bacteria can utilise specific gene targets, however in order to do this, prior knowledge of the sequence is required, so that a specific assay may be developed. The advantage of using specific oligonucleotide primers is that they should confer a higher degree of specificity than employing universal or broad-range primers. Examples of specific targets that have been employed include the use of the hippuricase gene for the differentiation of hippurate-hydrolysing campylobacters (Camp. jejuni) from non-hydrolysing campylobacters (Slater and Owen 1997) or the use of ctrA gene for meningococci in the laboratory diagnosis of meningococcal meningitis (Guiver et al., 2000). The specific target does not necessarily have to be associated with a PCR assay, but may be used in combination with several other nucleic acid amplification/analysis techniques (see Table 3).

Presently, there are several hundred specific assays available for the identification of a diverse variety of bacteria and too numerous to detail in this section. However, the end user of a given assay should be aware that each assay is potentially troubled with several pitfalls of poor assay design, which may lead to poor specificity and/or sensitivity. Therefore, before any assay is adopted into routine diagnostic service, the published method must firstly be empirically optimised in the end user's laboratory and that the user has an appreciation of the strengths and

\begin{tabular}{|c|c|}
\hline Sequence identification tools & Nucleotide sequence databases \\
\hline $\begin{array}{l}\text { BLASTn (Basic Local Alignment Sequence Tool) } \\
\text { http://www.ncbi.nlm.nih.gov/blast/ (USA) } \\
\text { http://dove.embl-heidelberg.de/Blast2/ (Germany) } \\
\text { http://www.ebi.ac.uk/blast/index.html (UK) } \\
\text { http://www-btls.jst.go.jp/ (Japan) }\end{array}$ & $\begin{array}{l}\text { http://www.ebi.ac.uk/embl/(UK) } \\
\text { http://www.ddbj.nig.ac.jp/ (Japan) } \\
\text { http://www.ncbi.nlm.nih.gov/Genbank/GenbankSearch.html }\end{array}$ \\
\hline \multicolumn{2}{|l|}{$\begin{array}{l}\text { FASTA } \\
\text { http://www.ebi.ac.uk/fasta33/ }\end{array}$} \\
\hline $\begin{array}{l}\text { OTHER } \\
\text { Ribosomal database project (www.cme.meu.edu/RDP/html/index.html) } \\
\text { MicroSeq (Commercial) (www.appliedbiosystems.com) } \\
\text { SmartGene IDNA (Commercial) (www.smartgene.ch) }\end{array}$ & \\
\hline
\end{tabular}




\begin{tabular}{|c|c|}
\hline Specimen & Reference \\
\hline Amniotic fluid & Jalava et al. (1996) \\
\hline Arterio-embolic tissue & Mueller et al. (1999) \\
\hline Ascitic fluid & Such et al. (2002) \\
\hline Atheroma & Apfalter et al. (2002) \\
\hline Blood culture & Millar et al. (2001) \\
\hline Blood-EDTA & Xu et al. (2003) \\
\hline Bone & Harris et al. (2002) \\
\hline Bone marrow & Gamboa et al. (1997) \\
\hline Breast milk & Schmidt et al. (1995) \\
\hline Bronchioelar lavage (BAL) & Ersch et al. (2000) \\
\hline Cerebral spinal fluid (CSF) & Saravolatz et al. (2003) \\
\hline Cervical specimen/tissue & Lehmann et al. (1999) \\
\hline Culture isolate (pure in vitro) & Millar et al. (2001) \\
\hline Feces & Kabir (2001) \\
\hline Fixed tissue sample & Wu et al. (2002) \\
\hline Heart valve & Gauduchon et al. (2003) \\
\hline Lymph node tissue & Yamada et al. (2002) \\
\hline Middle ear fluid & Jero et al. (1999) \\
\hline Nasal polyps/sinus/lavage & Bucholtz et al. (2002) \\
\hline Paraffin-embedded tissue & Yamada et al. (2002) \\
\hline Pus (wound and blister) & Berger et al. (2001); Kox et al. (1995) \\
\hline Plasma & Klaschik et al. (2002) \\
\hline Pleural effusion/fluid & Yanagihara et al. (2002) \\
\hline Prosthetic device & Tunney et al. (1999) \\
\hline Saliva & Sakamoto et al. (2002) \\
\hline Semen/sperm & Gdoura et al. (2001) \\
\hline Serum & Such et al. (2002) \\
\hline Skin & Torres et al. (2003); Enzensberger et al. (2002) \\
\hline Sputum & McDowell et al. (2001) \\
\hline Swabs & Torres et al. (2003) \\
\hline Synovial fluid & Vander Heijden et al. (1999) \\
\hline Tissue (wound) & Hill et al. (2003) \\
\hline Urine & Mahony et al. (1997) \\
\hline Vaginal fluid & Obata-Yasuoka et al. (2002) \\
\hline Vitreous humour & Sharma et al. (2002) \\
\hline \multicolumn{2}{|l|}{ Nucleic acid extraction } \\
\hline Alkali/heat lysis & Millar et al. (2000) \\
\hline Automated DNA extraction (e.g. MagNAPure) & Raggam et al. (2002) \\
\hline Boil & Clarke et al. (2003) \\
\hline Centrifugation/Chelex-100/boil & Schmidt et al. (1995) \\
\hline Commercial Kits (e.g., Qiagen/Roche) & Millar et al. (2000); Clarke et al. (2003) \\
\hline "In house methods" & Millar et al. (2000) \\
\hline Phenol/chloroform & Moore et al. (2002) \\
\hline Silica capture/guanidine hydrochloride treatment/proteinase K/lysozyme & Millar et al. (2000) \\
\hline
\end{tabular}

weaknesses of the assay, so that interpretation of the end result is easier to make.

\section{Antibiotic resistance markers}

Recently, antibiotic resistance in bacterial pathogens has become an important topic both nationally and internationally. Some scientists are forecasting the emergence of the "post antibiotic era", where it will be difficult to control common infections, due to the emergence of high level resistance in several medically important bacterial pathogens. Consequently, there has been great interest in being able to detect antibiotic 


\begin{tabular}{|c|c|}
\hline & Reference \\
\hline \multicolumn{2}{|l|}{ Nucleic acid amplification/analysis } \\
\hline Block-based PCR & Tang et al. (1997) \\
\hline- single round & Millar et al. (2001) \\
\hline - semi-nested & Moore et al. (2002) \\
\hline- nested & Hinrikson et al. (2000) \\
\hline - multiplex & Weaver and Rowe (1997) \\
\hline Branched DNA signal amplification & Tang et al. (1997); Zheng et al. (1999) \\
\hline DNA-hybridization/probe assay & Tang et al. (1997) \\
\hline In situ PCR/RT-PCR & Jin and Lloyd (1997) \\
\hline Ligase chain reaction (LCR) & $\begin{array}{l}\text { Blocker et al. (2002); Bachmann et al. (2002); Wang and Tay (2002); Gilpin et al. } \\
\text { (2002); Castriciano et al. (2002); Rajo et al. (2002); Friese et al. (2001) }\end{array}$ \\
\hline Microarrays & Anthony et al. (2001) \\
\hline Nucleic acid sequence-based amplification (NASBA) & Cook (2003); Cook et al. (2002) \\
\hline PCR-target capture/hybrid capture & Maibach et al. (2002) \\
\hline$Q \beta$ replicase system & Tang et al. (1997); An et al. (1995) \\
\hline Real-time PCR & Klaschik et al. (2002) \\
\hline -Light cycler & O’Mahony et al. (2002) \\
\hline -Taqman & Ellerbrook et al. (2002) \\
\hline Reverse transcriptase PCR (RT-PCR) & Tang et al. (1997) \\
\hline Strand displacement amplification (SDA) & Ge et al. (2002) \\
\hline Transcription mediated amplification (TMA) & Hill (2001) \\
\hline \multicolumn{2}{|l|}{ Characterization/Identification of amplicon } \\
\hline Automated sequence analysis & Patel (2001) \\
\hline DNA-DNA hybridization & Siqueira et al. (2001) \\
\hline Enzyme immunoassay (PCR-EIA) & Moreno et al. (2003) \\
\hline Restriction enzyme analysis (PCR-REA) & Brown and Levett (1997) \\
\hline Restriction fragment length polymorphism (RFLP) & McDowell et al. (2001) \\
\hline Single-strand conformational polymorphism (SSCP) & Kerr and Curran (1996); Hein et al. (2003) \\
\hline \multicolumn{2}{|l|}{ Genotyping/Molecular Epidemiology } \\
\hline Amplified fragment length polymorphism (AFLP) & Moreno et al. (2002) \\
\hline Arbitrary-primed - PCR (AP-PCR) & Dabrowski et al. (2003) \\
\hline Multilocus sequence typing (MLST) & Enright and Spratt (1999) \\
\hline Pulsed field gel electrophoresis (PFGE) & Wu and Della-Latta (2002) \\
\hline Random amplification of polymorphic DNA-(RAPD) & Power (1996) \\
\hline - BOX PCR & Gillespie (1999) \\
\hline - ERIC PCR & Marty (1997) \\
\hline - rep PCR & Baldy-Chudzik (2001) \\
\hline Ribotyping & Moore et al. (2002a) \\
\hline Single-strand conformational polymorphism (SSCP) & Kerr and Curran (1996); Hein et al. (2003) \\
\hline
\end{tabular}

resistance molecular, particularly when the causal agent is fastidious or non-culturable. Fluit et al., (2001) have recently published an authoritative review on the molecular detection of antibiotic resistance. Currently, most hospitals are concerned with the occurrence of methicillin resistance Staphylococcus aureus (MRSA) and glycopeptide resistant enterococci (GRE) on their wards, particularly surgical wards. Several workers have published molecular methods to detect MRSA through employment of a simple PCR assay, targeting the mecA gene locus (Kobayashi et al., 1994; Towner et al., 1998). The employment of mecA PCR to screen for carrier status of patients in the intensive care unit (ICU) is a useful tool to allow infection control teams to segregate positive MRSA patients from non-colonised patients, thereby minimising the opportunity for nosocomial spread amongst ICU patients. Application of such an assay also demonstrates that for this screening policy to be effective, the host laboratory should be in a position to perform the assays locally and not rely on sending cultures to a Reference laboratory.

\section{Genomovar analysis of Burkholderia cepacia in cystic fibrosis}

Infection with the Burkholderia cepacia complex (BCC) is an important cause of increased morbidity and reduced 
survival in patients with cystic fibrosis (CF) (Høiby 1991). Certain members of the BCC are transmissible and epidemics have been described in a number of CF centres (Doring et al., 1996). A number of factors such as the presence of the $B$. cepacia epidemic strain marker (BCESM) (Mahenthiralingam et al., 1997) and the cable pilus gene (Sajjan et al., 1995) have been identified as markers of transmissibility. Most units in the UK now segregate patients with this infection from all other CF patients and infection control guidelines have been recently published by the UK CF Trust (Anon., 1999) to help reduce the potential for cross infection with these organisms. Nine genomovars of the BCC have now been formally described and initial studies indicate that genomovar II has less clinical impact than genomovar III (De Soyza et al., 2000). Presently B. cenocepacia (formerly genomovar III) followed by Burkholderia multivorans (formerly $B$. cepacia genomovar II) make up the majority of patients infected with BCC. Some centres now segregate patients with different genomovar types eg., genomovar III patients from other B. cepacia complex infected patients (e.g. Belfast and Vancouver) to reduce the risk of cross infection between patients with BCC. Presently some centres believe that complete segregation of all the genomovar types is the best policy, whilst others feel that it is only important to segregate genomovar III from the other BCC types. Early accurate identification of BCC is of critical importance so the patients can be segregated and therefore reduce the potential for further epidemics. BCC organisms present the clinical microbiologist with a diagnostic dilemma, in that there are extremely few and in some cases no phenotypic biochemical or growth-related characterization tests that reliably distinguish between these organisms. To this end, there have been a variety of different molecular-based characterization tests to differentiate the genomovars (Segonds et al., 1999; LiPuma, 111999). Recently, the recA gene has been shown to aid in the differentiation of the genomovars (Mahenthiralingam 2000). RecA is a multifunctional and ubiquitous protein involved in general genetic recombination events and in DNA repair. It regulates the synthesis and activity of DNA repair (SOS induction) and catalyses homologous recombination and mutagenesis. As this locus may contribute significantly to the overall genomic plasticity of the BCC, this locus is potentially a strong candidate for the adoption of rapid molecular-based assays in the laboratory. Furthermore, molecular methods may aid CF centres in helping determine the status of CF patients with regard to whether they are chronically, transiently or not colonised with this pathogen.

\section{Molecular diagnostic procedures}

Most molecular assays rely on three basic components, including nucleic acid extraction, amplification/analysis and detection of an amplified product, as outlined in Table 3. Most molecular assays allow for a wide variety of permutations and combinations of methods, depending on what is trying to be achieved. For example, almost all clinical specimen types have been extracted by a variety of DNA extraction protocols. Choice of nucleic acid amplification/analysis may be varied, however presently, application of "real-time" platforms including the Roche LightCycler and the ABI Taqman 7700 systems are popular, as these not only allow detection in a relatively short time in a gel-less system, but also for the quantification of copy numbers. There are several factors which help determine which type of assay to employ (see Table 4). If speed is an important factor of the assay, e.g. detection of meningococcal DNA in CSF from children with suspected meningitis, employment of the real-time assays should be adopted. Where numerous targets are important, the multiplex PCR format should be employed.

\section{Laboratory management of molecular assays}

All molecular assays, due to their high sensitivity, are prone to contamination problems, which has the potential to lead to false-positives, thus diminishing the effectiveness of such testing regimes and thus strict contamination controls need to be established to avoid the occurrence of such problems. The use of broad-range PCR is particularly susceptible to contamination problems (Millar et al., 2002) and it has also been argued that such problems are indeed not unique to broad-range PCR, but that can be equally applied to specific PCR (Bastien et al., 2003). From clinical specimen reception to molecular analysis, there are numerous sources of contamination risk and for each molecular assay these should be identified and appropriate control measures identified and established to minimize each risk (see Table 5 for working example). To ensure the minimum contamination risk, including PCR amplicon carry-over, a key element is successful workflow through geographically separated areas. It is recognized that many diagnostic facilities in hospital laboratories have limited work space or have poor quality work space that makes separation of preand post-PCR areas difficult to achieve. However, it is important that adequate space is allocated to ensure compliance and to conform to CPAAccredittion standards for molecular diagnosis (Anon., 1999).

Successful employment of PCR in the detection of causal agents of infectious disease is critically dependent on both the quantity and quality of controls associated with the assay, to avoid the occurrence of both false-positive and false-negative results. Table 6 lists the reasons for false-positive and false-negative findings. It should be noted that for each PCR-based test, sensitivity should be evaluated for each specimen type, prior to routine implementation. It is vital that several negative and positive controls are set up during each diagnostic run. Negative and positive controls should include (a) DNA extraction control, (b) PCR set up control and (c) PCR amplification control. For DNA extraction purposes, the positive control should include clinical specimen artificially spiked with organism, e.g. blood culture spiked with E. coli. For clinical tissue specimens where a true positive specimen may be difficult to mimic, internal positive controls may be employed, such as following DNA extraction, amplification of the $\beta$-globin gene, as previously described (Millar et al., 2001). With respect to PCR controls, the positive control should be bacterial DNA extracted from a pure culture. Ideally, the positive control should include two components, namely: (i) a specimen generating a weak signal, due to low copy numbers of target and (ii) a specimen generating 
Table 4. Criteria used in the determination of the most appropriate molecular method for use in bacterial infections.

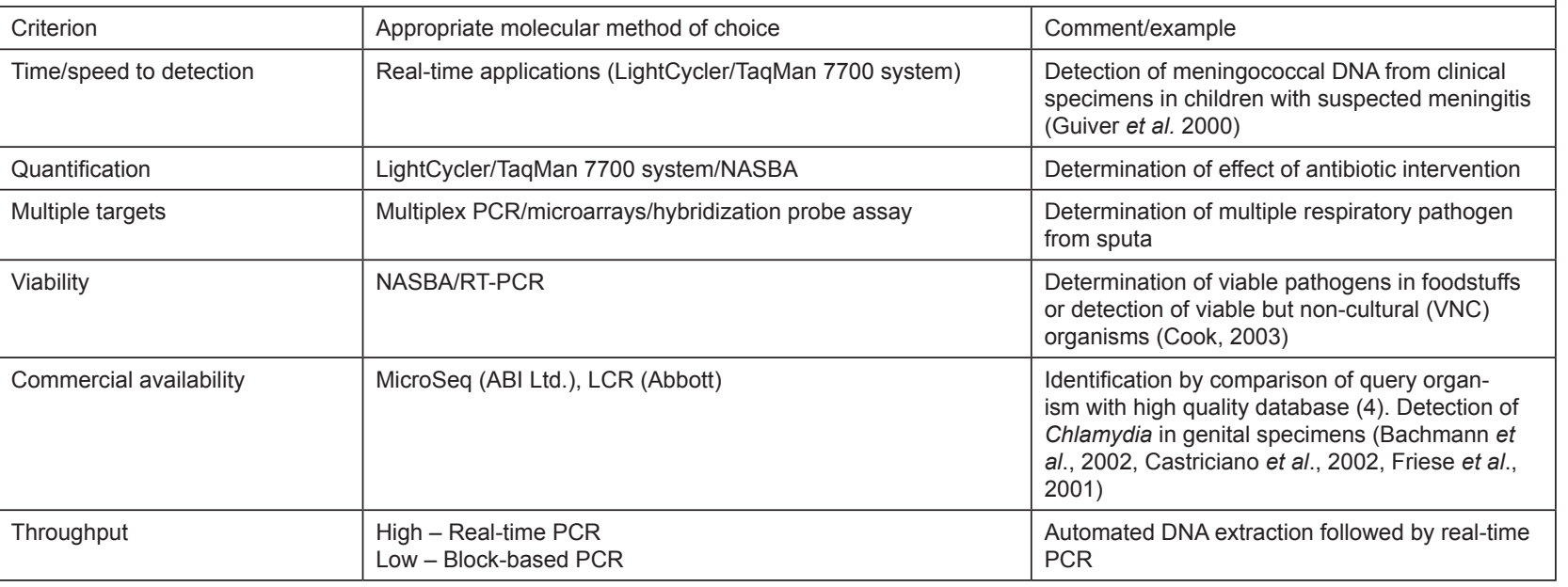

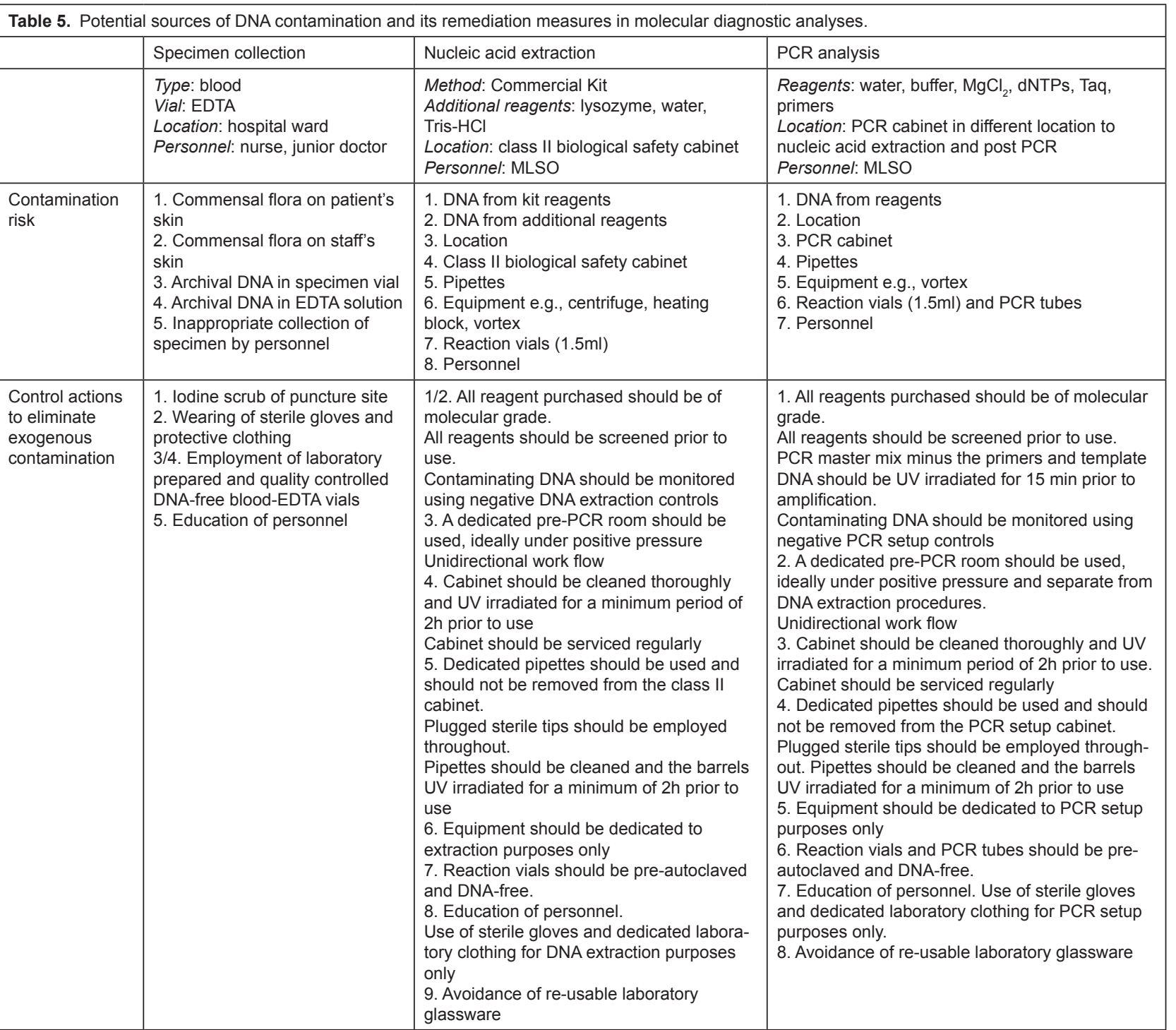




\begin{tabular}{|l|l|}
\hline \multicolumn{2}{|l|}{ Table 6. Most common factors contributing towards false positive and false negative results in molecular diagnostic assays. } \\
\hline Reasons for false-positive results & Reasons for false-negative results \\
\hline Carry over contamination (amplicons) from previously amplified products & Inhibition of PCR reaction \\
\hline $\begin{array}{l}\text { Presence of exogenous target DNA in reagents, water, kits, sterile blood } \\
\text { culture material }\end{array}$ & $\begin{array}{l}\text { Inadvertent loss of template nucleic acid target due to poor extraction, } \\
\text { handling and storage protocols }\end{array}$ \\
\hline Poor primer design (non-specificity) & Digestion of nucleic acid template with endogenous DNAses and RNAses \\
\hline Inadequate amplification conditions & Poor primer design (non-conserved regions at primer site(s) in variants) \\
\hline Contamination from laboratory personnel & $\begin{array}{l}\text { Poor intrinsic sensitivity of nucleic acid amplification/analysis detection } \\
\text { system } \\
\text { Poor sensitivity of nucleic acid amplification/analysis reaction } \\
\text { Poor specificity } \\
\text { Inadequate amplification conditions }\end{array}$ \\
\hline
\end{tabular}

a strong signal, due to high copy numbers of target. By employing these controls especially the negative controls, it is easier to identify the point of contamination within the diagnostic assay e.g., DNA extraction contamination free but contaminated at PCR set up stage. Positive controls are also important, particularly those included in the DNA extraction procedures, as they serve to identify possible inhibition of the PCR reaction, due to inhibitory agents in the biological specimen, which co-elute with extracted DNA, e.g. sodium polyanetholesulfonate in blood culture material (Millar et al., 2001). For a comprehensive review on PCR inhibition with respect to biological specimens, see Wilson (Wilson 1997).

\section{Standardization and harmonization}

Presently there are numerous molecular methodologies for the identification and genotyping of both culturable and non-culturable bacterial causal agents of infection. Although various commercial approaches have been described, such as the MicroSeq PCR-DNA sequencing identification system, the majority of methods used in clinical microbiology laboratories are "in-house". To date, there has been little or no attempts made to standardize and harmonize bacterial detection protocols between laboratories at a local, national and international level, although several European centres have attempted to examine these for specific organisms (Struelens and others 1996; Deplano et al., 2000; Dijkshoorn et al., 2001; Fry et al., 1999; Grundmann et al., 1997; Van Belkum et al., 1998). The disadvantage of not employing such standardized methods may lead to anomalies in the epidemiologically, which may yield bias results and hence corrupt the epidemiological reporting of a variety of infectious disease states. Most diagnostic laboratories employ methods, which are not completely consistent with their peer laboratories, e.g. employment of a published method with variations in the empirical optimization and/or with different reagent suppliers. Presently, there are limited studies detailing the effect of such variation on qualitative reporting of results and hence this area requires urgent attention. More recently, various focussed attempts have been made to try to standardize bacterial subtyping techniques, through the actions of PulseNet (http://www.cdc.gov/pulsenet/), primarily for bacterial foodborne disease surveillance in the US and the ESF Network for Exchange of Microbial Typing Information European Network (ENEMTI) (http://lists.nottingham. ac.uk/mailman/listinfo/enemti). ENEMTI is a network of European laboratories that aims to standardize methods and data exchange protocols for internet-based comparison of microbial fingerprinting data. This project aims to develop an internet-based database system for DNA fingerprints that is readily accessible and userfriendly for microbiologists with only limited computer expertise. In addition, the European Society for Clinical Microbiology and Infectious Disease (ESCMID) have a specific working group, namely the ESCMID Study Group on Epidemiological Markers (ESGEM), whose objectives are to (a) critically evaluate microbiological typing systems and make recommendations for their appropriate use, (b) promote collaborative research into microbiological typing systems and to develop standardized methodology for specific pathogens, (c) provide a forum for the exchange of ideas and the development of consensus strategies and (d) work with individuals and companies active in this research area to foster the development of further technological advances in microbial typing (http://www. escmid.org/sites/index f.asp?par=2.5).

\section{Appraisal of molecular diagnostics in clinical bacteriology}

Molecular diagnostics have several advantages and disadvantages for their adoption into routine bacteriology, as detailed in Table 7. At present, employment of molecular diagnostics is largely confined to specialized or reference bacteriology laboratories, due to several factors. With such an approach, molecular methodologies including PCR, real-time PCR and PFGE may have the opportunity to become adopted by several regional diagnostic laboratories outside of highly specialized reference facilities, as such methodologies have been shown to provide valuable real-time information to aid in outbreak management and identification of nonculturable or fastidious organisms. To date, the speed in which these assays have been taken up has been closely related to the relative skills base within the laboratory, thus although there is an advantage in all hospital types utilising such technology i.e. from the district general to university teaching hospitals, such techniques have not become common where the skills base does not exist. Furthermore, there is the added danger that hospital research facilities, which have been the custodians of these research techniques to date, become overloaded with a molecular diagnostic workload, simply because they have the necessary skills base. In addition, molecular techniques are perceived to be relatively expensive, which is the case on a simple head-to-head comparison (Table 8). The overall value of the quality of the test result, 


\begin{tabular}{|c|c|c|}
\hline Diagnostic criterion & Advantages & Disadvantages \\
\hline Accuracy of identification & $\begin{array}{l}\text { Aid in identifying aetiological agents of infections } \\
\text { which are difficult to culture, including: } \\
\text { Negative cultures } \\
\text { Expensive cultures } \\
\text { Slow growing organisms } \\
\text { Fastidious organisms } \\
\text { Cell-dependent organisms } \\
\text { Category } 3 \text { cultures where a designated secure } \\
\text { cell culture laboratory is required } \\
\text { Difficult, specific culture requirements where } \\
\text { limited serological tests exist } \\
\text { identification of causal agent following antibiotic } \\
\text { therapy }\end{array}$ & $\begin{array}{l}\text { Problems associated with contaminant organisms, however } \\
\text { these problems may be aided by inclusion of appropriate } \\
\text { DNA extraction and PCR controls (Millar et al. 2002) } \\
\text { The agent identified should be considered with respect to the } \\
\text { patient's medical and general history }\end{array}$ \\
\hline $\begin{array}{l}\text { Time to detection } \\
\text { Where specimens are: } \\
\text { a. culture-positive and/or serol- } \\
\text { ogy-positive } \\
\text { b. culture-negative and/or serol- } \\
\text { ogy-positive }\end{array}$ & $\begin{array}{l}\text { Confirmation of conventional detection result } \\
\text { more rapid detection than conventional culture for } \\
\text { fastidious and cell-dependent organisms } \\
\text { Confirmation of serology result. Detect and high- } \\
\text { light non-specific serological false-positive results }\end{array}$ & $\begin{array}{l}\text { Longer time required for molecular PCR and sequence } \\
\text { analysis than culture \& serology for non-fastidious or cell- } \\
\text { dependent organisms } \\
\text { Longer time required for molecular PCR and sequence } \\
\text { analysis than serology }\end{array}$ \\
\hline $\begin{array}{l}\text { c. culture-negative and serology- } \\
\text { negative }\end{array}$ & $\begin{array}{l}\text { Identification of causal agent when all conven- } \\
\text { tional diagnostic assays are negative }\end{array}$ & \\
\hline Impact on therapy & $\begin{array}{l}\text { Appropriate antibiotic therapy can be commenced } \\
\text { sooner or modified earlier in the presence of a } \\
\text { molecular identification from a culture-negative/se- } \\
\text { rology-negative specimen } \\
\text { Provision for PCR detection of antimicrobial } \\
\text { resistance gene determinants in culture-negative } \\
\text { PCR-positive specimen }\end{array}$ & \\
\hline Cost-effectiveness & $\begin{array}{l}\text { Cost-effective particularly with culture-negative/ } \\
\text { serology-negative specimens to avoid extended } \\
\text { analysis for several potential pathogens either by } \\
\text { specific culture and serological testing. } \\
\text { Economic and early use of most appropriate cost- } \\
\text { effective antibiotic treatment regimen } \\
\text { Economic and optimised in-patient stay }\end{array}$ & $\begin{array}{l}\text { Not cost effective when conventional culture and serology } \\
\text { give quality and early identification result } \\
\text { Specialised equipment } \\
\text { Necessary to purchase/lease specialised equipment usually } \\
\text { with costly maintenance contracts } \\
\text { Space allocation } \\
\text { Lack of education in modern molecular based technologies } \\
\text { Medical laboratory scientific officers, clinical scientists and } \\
\text { medical microbiologists all must understand the principles of } \\
\text { molecular based technologies to ensure proper handling of } \\
\text { the specimens and appropriate interpretation and significance } \\
\text { of results (Moore and Millar 2002), hence specific training } \\
\text { must be given }\end{array}$ \\
\hline
\end{tabular}

Table 8. Comparison of financial cost of identification of a bacterial culture employing phenotypic and genotypic identification schemes.

\begin{tabular}{|c|c|c|c|}
\hline \multicolumn{2}{|c|}{ Routine/conventional (API) identification } & \multicolumn{2}{|c|}{ Molecular (16S rDNA PCR \& sequencing) identification } \\
\hline Consumable item & Approx. cost (GBP £) (ex VAT) & Consumable item & Approx. cost (GBP £) (ex VAT) \\
\hline $1 \times$ API20NE strip & $3-95$ & DNA extraction kit & $2-50$ \\
\hline \multirow[t]{10}{*}{ API diagnostic reagents ${ }^{a}$} & $0-80$ & PCR reagents (not including primers) & $0-12$ (Taq) + 0-14 (dNTPs) \\
\hline & & Gel electrophoresis & $1-09$ \\
\hline & & Plasticware consumables & $1-50$ \\
\hline & & Specialist reagents (TAE, Tris, EtBr, etc) & $0-10$ \\
\hline & & PCR primers (forward and reverse) & $0-10$ \\
\hline & & PCR sub-total costs & $5-55 \times 2=11-10$ \\
\hline & & Sequencing kit & $1-96$ \\
\hline & & Polyacrylamide gel ${ }^{b}$ & $0-93$ \\
\hline & & Plasticware consumables & $1-50$ \\
\hline & & Sequencing sub-total costs & $4-59 \times 2=9-18$ \\
\hline TOTAL & $4-75$ & & $20-28$ \\
\hline
\end{tabular}


however, should be taken into account in terms of several parameters, including time-to-detection and ability to detect an agent. Although the use of a molecular test is albeit more expensive, its employment may yield a finding that could potentially reduce costs significantly further downstream with patient management.

In conclusion, molecular diagnostic techniques have a significant role to play in clinical bacteriology, although their adoption will never replace conventional methodologies, which continue to be the cornerstone of modern bacteriological methods. Indeed, such molecular diagnostic assays may only be implemented in specialized laboratories to enhance laboratory diagnostic efficiency, where the use of such assays will be mainly confined to diagnosis, identification and genotyping, where current conventional approaches are grossly inadequate. Adoption of such methods in bacteriology has occurred at a much slower rate than in clinical virology, where the inadequacies of conventional virology, has accelerated the adoption of molecular methods. Integration of molecular approaches in clinical bacteriology will be enhanced through the production of a greater range of diagnostic kits, as well as the existence of more accredited laboratories.

\section{References}

An, Q., Liu, J., O’Brien, W., Radcliffe, G., Buxton, D., Popoff, S., King, W., Vera-Garcia, M., Lu, L., and Shah, J. (1995). Comparison of characteristics of $Q$ beta replicase-amplified assay with competitive PCR assay for Chlamydia trachomatis. J. Clin. Microbiol. 33, 5863.

Anon. (1999). Infection Control Guidelines: Burkholderia cepacia. UK Cystic Fibrosis Trust, Bromley, Kent, England.

Anon. (1999). Additional guidance for inspectors use of molecular biology techniques in clinical pathology. pp. 1-9. Clinical Pathology Accreditation (UK) Ltd., London.

Anthony, R.M, Brown, and T.J, French, G.L. (2000). Rapid diagnosis of bacteremia by universal amplification of 235 ribosomal DNA followed by hybridization to an oligonucleotide array. J. Clin. Microbiol. 38, 781-788.

Anthony, R.M., Brown, T.J., and French, G.L. (2001). DNA array technology and diagnostic microbiology. Expert. Rev. Mol. Diagn. 1, 30-38.

Apfalter, P., Assadian, O., Blasi, F., Boman, J., Gaydos, C.A., Kundi, M., Makristathis, A., Nehr, M., Rotter, M.L., and Hirschl, A.M. (2002). Reliability of nested PCR for detection of Chlamydia pneumoniae DNA in atheromas: results from a multicenter study applying standardized protocols. J. Clin. Microbiol. 40, 4428-4434.

Bachmann, L.H., Desmond, R.A., Stephens, J., Hughes, A., and Hook, E.W. (2002). Duration of persistence of gonococcal DNA detected by ligase chain reaction in men and women following recommended therapy for uncomplicated gonorrhea. J. Clin. Microbiol. 40, 35963601.

Bailey, E.A.. Solomon, L.R., Berry, N., Cheesbrough, J.S., Moore, J.E., Jiru, X., Wareing, D.R., Harrison, T., and Pitcher, D. (2002). Ureaplasma urealyticum CAPD peritonitis following insertion of an intrauterine device: diagnosis by eubacterial polymerase chain reaction. Perit. Dial. 22, 422-424.

Bakshi, C.S., Singh, V.P, Malik, M., Sharma, B., and Singh, R.K. (2002). Polymerase chain reaction amplification of 16S-23S spacer region for rapid identification of Salmonella serovars. Acta. Vet. Hung. 50, 161-166.

Baldy-Chudzik, K. (2001) Rep-PCR - a variant to RAPD or an independent technique of bacteria genotyping? A comparison of the typing properties of rep-PCR with other recognised methods of genotyping of microorganisms. Acta. Microbiol. Pol. 50, 189-204.

Bastien, P., Chabbert, E. and Lauchaud, L. (2003). Contamination management of broad-range or specific PCR: Is there any difference? J. Clin. Microbiol. 41, 2272.

Berger, C., Altwegg, M., Meyer, A., and Nadal D. (2001). Broad range polymerase chain reaction for diagnosis of rat-bite fever caused by Streptobacillus moniliformis. Pediatr. Infect. Dis. J. 20, 1181-1182.

Blocker, M.E., Krysiak, R.G., Behets, F., Cohen, M.S., and Hobbs, M.M. (2002) Quantification of Chlamydia trachomatis elementary bodies in urine by ligase chain reaction. J. Clin. Microbiol. 40, 3631-3634.

Brown, P.D., and Levett, P.N. (1997) Differentiation of Leptospira species and serovars by PCR-restriction endonuclease analysis, arbitrarily primed PCR and lowstringency PCR. J. Med. Microbiol. 46, 173-181.

Bucholtz, G.A., Salzman, S.A., Bersalona, F.B., Boyle, T.R., Ejercito, V.S., Penno, L., Peterson, D.W., Stone, G.E., Urquhart, A., Shukla, S.K., and Burmester, J.K. (2002). PCR analysis of nasal polyps, chronic sinusitis, and hypertrophied turbinates for DNA encoding bacterial 16 S rRNA. Am. J. Rhinol. 16, 169-173.

Carpousis, A.J. (2002). The Escherichia coli RNA degradosome: structure, function and relationship in other ribonucleolytic multienzyme complexes. Biochem. Soc. Trans. 30, 150-155.

Carroll, N.M., Jaeger, E.E.M., Choudhury, S., Dunlop, A.A.S., Matheson, M.M., Adamson, P., Okhravi, N., and Lightman, S. (2000). Detection of and discrimination between gram-positive and gram-negative bacteria in intraocular samples by using nested PCR. J. Clin. Microbiol. 38, 1753-1757.

Castriciano, S., Luinstra, K., Jang, D., Patel, J., Mahony, J., Kapala,J., and Chernesky, M. (2002). Accuracy of results obtained by performing a second ligase chain reaction assay and $\mathrm{PCR}$ analysis on urine samples with positive or near-cutoff results in the LCx test for Chlamydia trachomatis. J. Clin. Microbiol. 40, 26322634.

Clarke, L., Millar, B.C., and Moore, J.E. (2003). Extraction of genomic DNA from Pseudomonas aeruginosa: a comparison of three methods. Br. J. Biomed. Sci. 60, 34-35.

Cook, N. (2003). The use of NASBA for the detection of microbial pathogens in food and environmental samples. J. Microbiol. Methods 53,165-174.

Cook, N., Ellison, J., Kurdziel, A.S., Simpkins, S., and Hays, J.P. (2002). A nucleic acid sequence-based amplification method to detect Salmonella enterica serotype enteritidis strain PT4 in liquid whole egg. J. Food Prot. 65, 1177-1178. 
Cuchacovich, R., Japa, S., Huang, W.Q., Calvo, A., Vega, L., Vargas, R.B., Singh, R., Flores, D., Castro, I., and Espinoza, L.R. (2002). Detection of bacterial DNA in Latin American patients with reactive arthritis by polymerase chain reaction and sequencing analysis. J. Rheumatol. 29, 1426-1429.

Dabrowski, W., Czekajlo-Kolodziej, U., Medrala, D., and Giedrys-Kalemba, S. (2003). Optimisation of AP-PCR fingerprinting discriminatory power for clinical isolates of Pseudomonas aeruginosa. FEMS Microbiol. Lett. 218, 51-57.

Deplano, A., Schuermans, A., Van Eldere, J, Witte, W., Meugnier, H., Etienne, J., Grundmann, H., Jonas, D., Noordhoek, G.T,, Dijkstra, J., van Belkum, A., van Leeuwen, W., Tassios, P.T., Legakis, N.J., van der Zee, A., Bergmans, A., Blanc, D.S., Tenover, F.C., Cookson, B.C., O'Neil, G., and Struelens,M.J. (2000). Multicenter evaluation of epidemiological typing of methicillin-resistant Staphylococcus aureus strains by repetitive-element PCR analysis. J. Clin. Microbiol. 38, 3527-3533.

De Soyza, A., Corris, P.A., Archer, L., McDowell, A., Moore, J., Elborn, S., Dark, J.H., and Gould, K. (2000). Pulmonary transplantation for CF; The effect of $B$. cepacia genomovars on outcomes. Thorax 55 (Suppl 3), S35.

Dijkshoorn, L., Towner, K.J., Struelens M. (eds). (2001). New approaches for the generation and analysis of microbial typing data. Elsevier, Amsterdam.

Doring, G., Jansen, S., Noll, H., Grupp, H., Frank, F., Botzenhart, K., Magdorf, K., and Wahn, U. (1996). Distribution and transmission of Pseudomonas aeruginosa and Burkholderia cepacia in a hospital ward. Pediat. Pulmonol. 21, 90-100.

Ellerbrok, H., Nattermann, H., Ozel, M., Beutin, L., Appel, B., and Pauli, G. (2002). Rapid and sensitive Identification of pathogenic and apathogenic Bacillus anthracis by real-time PCR. FEMS Microbiol. Lett. 214, 51-59.

Enright, M.C., and Spratt, B.G. (1999). Multilocus sequence typing. Trends Microbiol. 7, 482-487.

Enzensberger, R., Hunfeld, K.P., Elshorst-Schmidt, T., Boer, A., and Brade, V. (2002). Disseminated cutaneous Mycobacterium marinum infection in a patient with nonHodgkin's lymphoma. Infect. 30, 393-395.

Ersch, J., Speich, R., Weber, R., Altwegg, M., and Hauser, M. (2000). Value of bronchoalveolar lavage in the diagnostic work-up of HIV-associated lung disease. Dtsch. Med. Wochenschr. 125, 789-793.

Farkas, D.H., Drevon, A.M., Kiechle, F.L., DiCarlo, R.G., Heath, E.M., and Crisan, D. (1996). Specimen stability for DNA-based diagnostic testing. Diagn. Mol. Pathol. $5,227-235$.

Feltham, J.L., and Gierasch, L.M. (2000). GroEL-substrate interactions: molding the fold, or folding the mold? Cell 100, 193-196.

Fluit, A.C., Visser, M.R., and Schmitz, F.J. (2001) Molecular detection of antimicrobial resistance. Clin. Microbiol. Rev. 14, 836-871.

Francis, K.P., and Stewart, G.S. (1997). Detection and speciation of bacteria through PCR using universal major cold-shock protein primer oligomers. J. Ind. Microbiol. Biotechnol. 19, 286-293.

Freise, J., Gerard, H.C., Bunke, T., Whittum-Hudson, J.A., Zeidler, H., Kohler, L., Hudson, A.P., and Kuipers, J.G. (2001). Optimised sample DNA preparation for detection of Chlamydia trachomatis in synovial tissue by polymerase chain reaction and ligase chain reaction. Ann. Rheum. Dis. 60, 140-145.

Fry, N.K., Alexiou-Daniel, S., Bangsborg, J.M., Bernander, S., Castellani Pastoris, M., Etienne, J., Forsblom, B., Gaia, V., Helbig, J.H., Lindsay, D., Christian Luck, P., Pelaz, C., Uldum, S.A., and Harrison, T.G. (1999). A multicenter evaluation of genotypic methods for epidemiologic typing of Legionella pneumophila serogroup 1: results of a pan-European study. Clin. Microbiol. Infect. 5, 462-477.

Gamboa, F., Manterola, J.M., Lonca, J., Matas, L., Vinado, B., Gimenez, M., Cardona, P.J., Padilla, E., and Ausina, V. (1997). Detection and identification of mycobacteria by amplification of RNA and DNA in pretreated blood and bone marrow aspirates by a simple lysis method. J. Clin. Microbiol. 35, 2124-2128.

Gauduchon, V., Chalabreysse, L., Etienne, J., Celard, M., Benito, Y., Lepidi, H., Thivolet-Bejui, F., and Vandenesch, F. (2003). Molecular diagnosis of infective endocarditis by PCR amplification and direct sequencing of DNA from valve tissue. J. Clin. Microbiol. 41, 763-766.

Gdoura, R., Keskes-Ammar, L., Bouzid, F., Eb, F., Hammami, A., and Orfila, J. (2001). Chlamydia trachomatis and male infertility in Tunisia. Eur. J. Contracept. Reprod. Health. Care 6, 102-107.

Ge, B., Larkin, C., Ahn, S., Jolley, M., Nasir, M., Meng, J., and Hall, R.H. (2002). Identification of Escherichia coli O157: $\mathrm{H} 7$ and other enterohemorrhagic serotypes by EHEC-hlyAtargeting, strand displacement amplification, and fluorescence polarization. Mol. Cell. Probes 16, 85-92.

Geissdorfer, W., Wittmann, I., Rollinghoff, M., Schoerner, C., and Bogdan, C. (2001). Detection of a new 16S-23S rRNA spacer sequence variant (type 7) of Tropheryma whippelii in a patient with prosthetic aortic valve endocarditis. Eur. J. Clin. Microbiol. Infect. Dis. 20, 762-763.

Gillespie, S.H. (1999). The role of the molecular laboratory in the investigation of Streptococcus pneumoniae infections. Semin. Respir. Infect. 14, 269-275.

Gilpin, C.M., Dawson, D.J., O’Kane, G., Armstrong, J.G., and Coulter, C. (2002). Failure of commercial ligase chain reaction to detect Mycobacterium tuberculosis DNA in sputum samples from a patient with smearpositive pulmonary tuberculosis due to a deletion of the target region. J. Clin. Microbiol. 40, 2305-2307.

Goh, S.H., Potter, S., Wood, J.O., Hemmingsen, S.M., Reynolds, R.P., Chow, A.W. (1996). HSP60 gene sequences as universal targets for microbial species identification: studies with coagulase-negative staphylococci. J. Clin. Microbiol. 34, 818-823.

Goldenberger, D., Kunzli, A., Vogt, P., Zbinden, R., and Altwegg, M. (1997). Molecular diagnosis of bacterial endocarditis by broad-range PCR amplification and direct sequencing. J. Clin. Microbiol. 35, 2733-2739. 
Grundmann, H.J., Towner, K.J., Dijkshoorn, L., GernerSmidt, P., Maher, M., Seifert, H., and Vaneechoutte, M. (1997). Multicenter study using standardized protocols and reagents for evaluation of reproducibility of PCRbased fingerprinting of Acinetobacter spp. J. Clin. Microbiol. 35, 3071-3077.

Guiver, M., Borrow, R., Marsh, J., Gray, S.J., Kaczmarski, E.B., Howells, D., Boseley, P., and Fox, A.J. (2000). Evaluation of the Applied Biosystems automated Taqman polymerase chain reaction system for the detection of meningococcal DNA. FEMS Immunol. Med. Microbiol. 28, 173-179.

Gurtler, V., and Stanisich, V.A. (1996). New approaches to typing and identification of bacteria using the $16 \mathrm{~S}$ 23S rDNA spacer region. Microbiology 142, 13-16.

Harris, K.A., Fidler, K.J., Hartley, J.C., Vogt, J., Klein, N.J., Monsell, F., and Novelli, V.M. (2002). Unique case of Helicobacter sp. osteomyelitis in an immunocompetent child diagnosed by broad-range $16 S$ PCR. J. Clin. Microbiol. 40, 3100-3103.

Hein, I., Mach, R.L., Farnleitner, A.H., and Wagner, M. (2003). Application of single-strand conformation polymorphism and denaturing gradient gel electrophoresis for fla sequence typing of Campylobacter jejuni. J. Microbiol. Methods 52, 305-313.

Hill, C.S. (2001). Molecular diagnostic testing for infectious diseases using TMA technology. Expert. Rev. Mol. Diagn. 1, 445-455.

Hill, K.E., Davies, C.E., Wilson, M.J., Stephens, P., Harding, K.G. and Thomas, D.W. (2003). Molecular analysis of the microflora in chronic venous leg ulceration. J. Med. Microbiol. 52, 365-369.

Hinrikson, H.P., Dutly, F., and Altwegg, M. (2000). Evaluation of a specific nested PCR targeting domain III of the 23S rRNA gene of "Tropheryma whippelii" and proposal of a classification system for its molecular variants. J. Clin. Microbiol. 38, 595-599.

Høiby N. (1991). Cystic fibrosis: infection. Schweiz. Med. Wochenschr. 121, 105-109.

Houpikian P, and Raoult, D. (2001). 16S/23S rRNA intergenic spacer regions for phylogenetic analysis, identification, and subtyping of Bartonella species. J. Clin. Microbiol. 39, 2768-2778.

Hryniewiecki, T., Gzyl, A., Augustynowicz, E., and Rawczynska-Englert, I. (2002). Development of broadrange polymerase chain reaction (PCR) bacterial identification in diagnosis of infective endocarditis. J. Heart Valve Dis. 11, 870-874.

Jalava, J., Mantymaa, M.L., Ekblad, U., Toivanen, P., Skurnik, M., Lassila, O., and Alanen, A. (1996). Bacterial $16 \mathrm{~S}$ rDNA polymerase chain reaction in the detection of intra-amniotic infection. Br. J. Obstet. Gynaecol. 103, 664-649.

Jero, J., Alakarppa, H., Virolainen, A., Saikku, P., and Karma, P. (1999). Polymerase chain reaction assay for detecting Chlamydia pneumoniae in middle ear fluid of children with otitis media with effusion. Pediatr. Infect. Dis. J. 18, 939-940.

Jin, L., and Lloyd, R.V. (1997). In situ hybridization: methods and applications. J. Clin. Lab. Anal. 11, 2-9.
Kabir, S. (2001). Detection of Helicobacter pylori in faeces by culture, PCR and enzyme immunoassay. J. Med. Microbiol. 50, 1021-1029.

Kerr, J.R., and Curran, M.D. (1996). Applications of polymerase chain reaction single stranded conformational polymorphism to microbiology. J. Clin. Path. Mol. Path. 49, M315-M320.

Klaschik, S., Lehmann, L.E., Raadts, A., Book, M., Hoeft, A., and Stuber, F. (2002). Real-time PCR for detection and differentiation of gram-positive and gram-negative bacteria. J. Clin. Microbiol. 40, 4304-4307.

Kobayashi, N., Kojima, K., Taniguchi, K., Urasawa, S., Uehara, N., Omizu, Y., Kishi, Y., Yagihashi, A., and Kurokawa, I. (1994). Detection of mecA, femA, and femB genes in clinical strains of staphylococci using polymerase chain reaction. Epidemiol. Infect. 113, 259-266.

Kolbert, C.P., and Persing, D.H. (1999). Ribosomal DNA sequencing as a tool for identification of bacterial pathogens. Curr. Opin. Microbiol. 2, 299-305.

Kox, L.F., van Leeuwen, J., Knijper, S., Jansen, H.M., and Kolk, A.H. (1995). PCR assay based on DNA coding for $16 \mathrm{~S}$ rRNA for detection and identification of mycobacteria in clinical samples. J. Clin. Microbiol. 33, 3225-3233.

Lehmann, M., Groh, A., Rodel, J., Nindl, I., and Straube, E. (1999). Detection of Chlamydia trachomatis DNA in cervical samples with regard to infection by human papillomavirus. J. Infect. 38, 12-17.

Ley, B.E., Linton, C.J., Bennett, D.M., Jalal, H., Foot, A.B., and Millar, M.R. (1998). Detection of bacteraemia in patients with fever and neutropenia using 16S rRNA gene amplification by polymerase chain reaction. Eur. J. Clin. Microbiol. Infect. Dis. 17, 247-253.

LiPuma, J.J., Dulaney, B.J, McMenamin, J.D., Whitby, P.W., Stull, T.L., Coenye, T., and Vandamme, P. (1999). Development of rRNA-based PCR assays for identification of Burkholderia cepacia complex isolates recovered from cystic fibrosis patients. J. Clin. Microbiol. 37, 3167-3170.

Madico, G., Quinn,T.C., Boman, J., and Gaydos, C.A. (2000). Touchdown enzyme time release-PCR for detection and identification of Chlamydia trachomatis, C. pneumoniae, and C. psittaci using the $16 \mathrm{~S}$ and $16 \mathrm{~S}-$ $23 S$ spacer rRNA genes. J. Clin. Microbiol. 38, 10851093.

Mahenthiralingam, E., Campbell, M.E., and Speert, D.P. (1997). Identification and characterization of a novel DNA marker associated with epidemic strains of Burkholderia cepacia recovered from patients with cystic fibrosis. J. Clin. Microbiol. 35, 808-816.

Mahenthiralingam, E., Bischof, J., Byrne, S.K., Radomski, C., Davies, J.E., Av-Gay, Y., and Vandamme, P. (2000). DNA-based diagnostic approaches for identification of Burkholderia cepacia complex, Burkholderia vietnamiensis, Burkholderia multivorans, Burkholderia stabilis, and Burkholderia cepacia Genomovars I and III. J. Clin. Microbiol. 38, 3165-3173.

Mahony, J.B., Jang, D., Chong, S., Luinstra, K., Sellors, J., Tyndall, M., and Chernesky, M. (1997). Detection of Chlamydia trachomatis, Neisseria gonorrhoeae, Ureaplasma urealyticum, and Mycoplasma genitalium 
in first-void urine specimens by multiplex polymerase chain reaction. Mol. Diagn. 2, 161-168.

Maibach, R.C., Dutly, F., and Altwegg, M. (2002). Detection of Tropheryma whipplei DNA in feces by PCR using a target capture method. Clin. Microbiol. 40, 2466-2471.

Marty, N. (1997). Epidemiological typing of Stenotrophomonas maltophilia. Hosp. Infect. 36, 261266.

Matsui, T., Matsuda, M., Murayama, O., Millar, B.C., and Moore, J.E. (2001). recA genotyping of Salmonella enteritidis phage type 4 isolates by restriction fragment length polymorphism analysis. Lett. Appl. Microbiol. 32, 424-427.

McDowell, A., Mahenthiralingam, E., Moore, J.E., Dunbar, K.E., Webb, A.K., Dodd, M.E., Martin, S.L., Millar, B.C., Scott, C.J., Crowe, M., and Elborn, J.S. (2001). PCRbased detection and identification of Burkholderia cepacia complex pathogens in sputum from cystic fibrosis patients. J. Clin. Microbiol. 39, 4247-4255.

Millar, B.C., Jiru, X., Moore, J.E., and Earle, J.A. (2000). A simple and sensitive method to extract bacterial, yeast and fungal DNA from blood culture material. J. Microbiol. Methods 42, 139-147.

Millar, B., Moore, J., Mallon, P., Xu, J., Crowe, M., McClurg, R., Raoult, D., Earle, J., Hone, R., and Murphy, P. (2001). Molecular diagnosis of infective endocarditis - a new Duke's criterion. Scand. J. Infect. Dis. 33, 673-680.

Millar, B.C., Xu, J., and Moore, J.E. (2002). Risk assessment models and contamination management: implications for broad-range ribosomal DNA PCR as a diagnostic tool in medical bacteriology. J. Clin. Microbiol. 40, 1575-1580.

Moore, J.E., Millar, B.C., Jiru, X., McCappin, J., Crowe, M., and Elborn, J.S. (2001a). Rapid characterization of the genomovars of the Burkholderia cepacia complex by PCR-single-stranded conformational polymorphism (PCR-SSCP) analysis. J. Hosp. Infect. 48, 129-134.

Moore, J.E, Millar, B.C., Yongmin, X., Woodford, N., Vincent, S., Goldsmith, C.E., McClurg, R.B., Crowe, M., Hone, R., and Murphy, P.G. (2001b). A rapid molecular assay for the detection of antibiotic resistance determinants in causal agents of infective endocarditis. J. Appl. Microbiol. 90, 719-726.

Moore, J.E. and Millar, B.C. (2002). Need for improved molecular biology training for biomedical scientists in NHS microbiology laboratories. Br. J. Biomed. Sci. 59, 180.

Moore, J.E., Lanser, J., Heuzenroeder, M., Ratcliff, R.M., Millar, B.C., and Madden. R.H. (2002a). Molecular diversity of Campylobacter coli and $C$. jejuni isolated from pigs at slaughter by flaA-RFLP analysis and ribotyping. J. Vet. Med. B Infect. Dis. Vet. Public Health 49, 388-393.

Moore, J.E., Xu, J., Millar, B.C., Crowe, M., Elborn, J.S. (2002b). Improved molecular detection of Burkholderia cepacia genomovar III and Burkholderia multivorans directly from sputum of patients with cystic fibrosis. J. Microbiol. Methods 49, 183-191.

Moreno, C., Kutzner, H., Palmedo, G., Goerttler, E., Carrasco, L., and Requena, L. (2003). Interstitial granulomatousdermatitiswith histiocyticpseudorosettes: a new histopathologic pattern in cutaneous borreliosis.
Detection of Borrelia burgdorferi DNA sequences by a highly sensitive PCR-ELISA. J. Am. Acad. Dermatol. 48, 376-384.

Moreno, Y., Ferrus, M.A., Vanoostende, A., Hernandez, M., Montes, R.M., and Hernandez, J. (2002). Comparison of $23 S$ polymerase chain reaction-restriction fragment length polymorphism and amplified fragment length polymorphism techniques as typing systems for thermophilic campylobacters. FEMS Microbiol. Lett. 211, 97-103.

Mueller, N.J., Kaplan, V., Zbinden, R., and Altwegg, M. (1999). Diagnosis of Cardiobacterium hominis endocarditis by broad-range PCR from arterio-embolic tissue. Infect. 27, 278-279.

Obata-Yasuoka, M., Ba-Thein, W., Hamada, H., and Hayashi, H. (2002). A multiplex polymerase chain reaction-based diagnostic method for bacterial vaginosis. Obstet. Gynecol. 100, 759-764.

O'Mahony, J., and Hill, C. (2002). A real time PCR assay for the detection and quantitation of Mycobacterium avium subsp paratuberculosis using SYBR Green and the Light Cycler. J. Microbiol. Methods 51, 283-293.

Patel, J.B. (2001). 16S rRNAgene sequencing for bacterial pathogen identification in the clinical laboratory. Mol. Diagn. 6, 313-321.

Patel, J.B., Leonard, D.G.B., Pan, X., Musser, J.M., Berman, R.E., and Nachamkin, I. (2000). Sequencebased Identification of Mycobacterium species using the MicroSeq 500 16S rDNA bacterial identification system. J. Clin. Microbiol. 38, 246-251.

Power, E.G. (1996). RAPD typing in microbiology--a technical review. J. Hosp. Infect. 34, 247-265.

Raggam, R.B., Leitner, E., Muhlbauer, G., Berg, J., Stocher, M., Grisold, A.J, Marth, E., and Kessler, H.H. (2002). Qualitative detection of Legionella species in bronchoalveolar lavages and induced sputa by automated DNA extraction and real-time polymerase chain reaction. Med. Microbiol. Immunol. (Berl.) 191, 119-125.

Rajo, M.C., Perez Del Molina, M.L., Lado Lado, F.L., Lopez, M.J., Prieto, E., and Pardo, F. (2002). Rapid diagnosis of tuberculous meningitis by ligase chain reaction amplification. Scand. J. Infect. Dis. 34, 14-16.

Roth, A., Reischl, U., Streubel, A., Naumann, L., Kroppenstedt, R.M., Habicht, M., Fischer, M., and Mauch, H. 2000. Novel diagnostic algorithm for identification of mycobacteria using genus-specific amplification of the 16S-23S rRNA gene spacer and restriction endonucleases. J. Clin. Microbiol. 38, 10941104.

Sajjan, U.S., Sun, L., Goldstein, R., and Forstner, J.F. (1995). Cable (Cb/) type Il pili of cystc fibrosis associated Burkholderia (Pseudomonas) cepacia: nucleotide sequence of the cblA major subunit pilin gene and novel morphology of the assembled appendage fibers. J. Bacteriol. 177, 1030-1038.

Sakamoto, M., Huang, Y., Umeda, M., Ishikawa, I., and Benno Y. (2002). Detection of novel oral phylotypes associated with periodontitis. FEMS Microbiol. Lett. 217, 65-69.

Saravolatz, L.D., Manzor, O., VanderVelde, N., Pawlak, J., and Belian, B. (2003). Broad-range bacterial polymerase 
chain reaction for early detection of bacterial meningitis. Clin. Infect. Dis. 36, 40-45.

Schabereiter-Gurtner, C., Lubitz, W., and Rolleke, S. (2003). Application of broad-range 16S rRNA PCR amplification and DGGE fingerprinting for detection of tick-infecting bacteria. J. Microbiol. Methods 52, 251260.

Schmidt, B.L., Aberer, E., Stockenhuber, C., Klade, H., Breier, F. and Luger, A. (1995). Detection of Borrelia burgdorferi DNA by polymerase chain reaction in the urine and breast milk of patients with Lyme Borreliosis. Diag. Microbiol Infect. Dis. 21, 121-128.

Segonds, C., Heulin, T., Marty, N., and Chabanon, G. (1999). Differentiation of Burkholderia species by PCRrestriction fragment length polymorphism analysis of the 16S rRNA gene and application to cystic fibrosis isolates. J. Clin. Microbiol. 37, 2201-2208.

Shang, S., Fu, J., Dong, G., Hong, W., Du, L., and Yu, X. (2003). Establishment and analysis of specific DNA patterns in 16S-23S rRNA gene spacer regions for differentiating different bacteria. Chin. Med. J. (Engl) 116, 129-133.

Sharma, S., Das, D., Anand, R., Das, T., and Kannabiran, C. (2002). Reliability of nested polymerase chain reaction in the diagnosis of bacterial endophthalmitis. Am. J. Ophthalmol. 133, 142-144.

Siqueira, J.F. Jr, Rjcas, I.N., Oliveira, J.C., and Santos, K.R. (2001). Detection of putative oral pathogens in acute periradicular abscesses by $16 \mathrm{~S}$ rDNA-directed polymerase chain reaction. J. Endod. 27, 164-167.

Slater, E.R., and Owen, R.J. (1997). Restriction fragment length polymorphism analysis shows that the hippuricase gene of Campylobacter jejuni is highly conserved. Lett. Appl. Microbiol. 25, 274-278.

Steege, D.A. (2000). Emerging features of mRNA decay in bacteria. RNA 6, 1079-1090.

Such, J., Frances, R., Munoz, C., Zapater, P., Casellas, J.A., Cifuentes, A., Rodriguez-Valera, F., Pascual, S., Sola-Vera, J., Carnicer, F., Uceda, F., Palazon, J.M., and Perez-Mateo, M. (2002). Detection and identification of bacterial DNA in patients with cirrhosis and culturenegative, nonneutrocytic ascites. Hepatology 36, 135141.

Struelens, M.J. and the Members of the European Study Group on Epidemiological Markers (ESGEM) of the European Society for Clinical Microbiology and Infectious Diseases (ESCMID). (1996). Consensus guidelines for appropriate use and evaluation of microbial epidemiologic typing systems. Clin. Microbiol. Infect. 2, 2-11.

Tang, Y.W., Procop, G.W., and Persing, D.H. (1997). Molecular diagnostics of infectious diseases. Clin. Chem. 43, 2021-2038.

Therese, K.L., Anand, A.R., and Madhavan, H.N. (1998). Polymerase chain reaction in the diagnosis of bacterial endophthalmitis. Br. J. Ophthalmol. 82, 1078-1082.

Torres, P., Camarena, J.J., Gomez, J.R., Nogueira, J.M., Gimeno, V., Navarro, J.C., and Olmos, A. (2003). Comparison of PCR mediated amplification of DNA and the classical methods for detection of Mycobacterium leprae in different types of clinical samples in leprosy patients and contacts. Lepr. Rev. 74, 18-30.
Towner, K.J., Talbot, D.C.S., Curran, R., Webster, C.A. and Humphreys, H. (1998). Development and evaluation of a PCR-based immunoassay for the rapid detection of methicillin-resistant Staphylococcus aureus. J. Med. Microbiol. 47, 1-7.

Tunney, M.M., Patrick, S., Curran, M.D., Ramage, G., Hanna, D., Nixon, J.R., Gorman, S.P., Davis, R.I., and Anderson, N. (1999). Detection of prosthetic hip infection at revision arthroplasty by immunofluorescence microscopy and PCR amplification of the bacterial 16S rRNA gene. J. Clin. Microbiol. 37, 3281-3290.

Van Belkum, A., Van Leeuwen, W., Kaufmann, M.E., Cookson, B., Forey, F., Etienne, J., Goering, R., Tenover, F., Steward, C., O'Brien, F., Grubb, W., Tassios, P., Legakis, N., Morvan, A., El Solh, N., de Ryck, R., Struelens, M., Salmenlinna, S., Vuopio-Varkila, J., Kooistra, M., Talens, A., Witte, W., and Verbrugh, H. (1998). Assessment of resolution and intercenter reproducibility of results of genotyping Staphylococcus aureus by pulsed-field gel electrophoresis of Smal macrorestriction fragments: a multicenter study. J. Clin. Microbiol. 36, 1653-1659.

van der Heijden, I.M., Wilbrink, B., Vije, A.E., Schouls, L.M., Breedveld, F.C., and Tak, P.P. (1999). Detection of bacterial DNA in serial synovial samples obtained during antibiotic treatment from patients with septic arthritis. Arthritis Rheum. 42, 2198-2203.

Wang, S.X., and Tay, L. (2002). Early identification of Mycobacterium tuberculosis complex in BACTEC cultures by ligase chain reaction. J. Med. Microbiol. 51, 710-712.

Weaver, J.W., and Rowe, M.T. (1997). Effect of non-target cells on the sensitivity of the PCR for Escherichia coli O157:H7. Lett. Appl. Microbiol. 25, 109-112.

Westergren, V., Bassiri, M., and Engstrand, L. (2003). Bacteria detected by culture and $16 \mathrm{~S}$ rRNA sequencing in maxillary sinus samples from intensive care unit patients. Laryngoscope 113, 270-275.

Whitby, P.W., Carter, K.B., Burns, J.L., Royall, J.A., LiPuma, J.J., and Stull, T.L. (2000). Identification and detection of Stenotrophomonas maltophilia by rRNAdirected PCR. J. Clin. Microbiol. 38, 4305-4309.

Wilson, I.G. (1997). Inhibition and facilitation of nucleic acid amplification. Appl. Environ. Microbiol. 63, 37413751.

Woese, C.R. (1987). Bacterial evolution. Microbiol. Rev. 51, 221-271.

Woo, P.C., Woo, G.K., Lau, S.K., Wong. S.S., and Yuen, K. (2002). Single gene target bacterial identification. groEL gene sequencing for discriminating clinical isolates of Burkholderia pseudomallei and Burkholderia thailandensis. Diagn. Microbiol. Infect. Dis. 44, 143149.

Woo, P.C., Fung, A.M., Lau, S.K., Chan, B.Y., Chiu, S.K., Teng, J.L., Que, T.L., Yung, R.W., and Yuen, KY. (2003). Granulicatella adiacens and Abiotrophia defectiva bacteraemia characterized by $16 \mathrm{~S}$ rRNA gene sequencing. J. Med. Microbiol. 52, 137-140.

Wu. L., Patten, N., Yamashiro, C.T., and Chui B. (2002). Extraction and amplification of DNA from formalin-fixed, paraffin-embedded tissues. Appl. Immunohistochem. Mol. Morphol. 10, 269-274. 
Wu, F., and Della-Latta, P. (2002). Molecular typing strategies. Semin. Perinatol. 26, 357-366.

$\mathrm{Xu}$, J., Moore, Millar, B.C., Crowe, M., McClurg, R and Heaney, L. (2003). Identification of a novel $\alpha$-Proteobacterium causing bacteraemia in an immunocompotent patient. J. Infect. 47, 167-169.

Xu, J., Millar, B.C., Moore, J.E., Murphy, K., Webb, H., Fox, A.J., Cafferkey, M., and Crowe, M.J. (2003). Employment of broad-range 16S rRNA PCR to detect aetiological agents of infection from clinical specimens in patients with acute meningitis--rapid separation of 16S rRNA PCR amplicons without the need for cloning. J. Appl. Microbiol. 94, 197-206.
Yamada, T., Eishi, Y., Ikeda, S., Ishige, I., Suzuki, T., Takemura, T., Takizawa, T., and Koike, M. (2002). In situ localization of Propionibacterium acnes DNA in lymph nodes from sarcoidosis patients by signal amplification with catalysed reporter deposition. J. Pathol. 198, 541547.

Yanagihara, K., Tomono, K., Sawai, T., Miyasaki,Y., Hirakata, Y., Kadota, J., and Kohno, S. (2002). Mycobacterium avium complex pleuritis. Respiration 69, 549-551.

Zheng, X., Kolbert, C.P., Varga-Delmore, P., Arruda, J., Lewis, M., Kolberg, J., Cockerill, F.R., and Persing, D.H. (1999). Direct mecA detection from blood culture bottles by branched-DNA signal amplification. J. Clin. Microbiol. 37, 4192-4193. 


\section{Further Reading}

Caister Academic Press is a leading academic publisher of advanced texts in microbiology, molecular biology and medical research. Full details of all our publications at caister.com

- MALDI-TOF Mass Spectrometry in Microbiology Edited by: M Kostrzewa, S Schubert (2016) www.caister.com/malditof

- Aspergillus and Penicillium in the Post-genomic Era Edited by: RP Vries, IB Gelber, MR Andersen (2016) www.caister.com/aspergillus2

- The Bacteriocins: Current Knowledge and Future Prospects Edited by: RL Dorit, SM Roy, MA Riley (2016)

www.caister.com/bacteriocins

- Omics in Plant Disease Resistance Edited by: V Bhadauria (2016) www.caister.com/opd

- Acidophiles: Life in Extremely Acidic Environments Edited by: R Quatrini, DB Johnson (2016) www.caister.com/acidophiles

- Climate Change and Microbial Ecology: Current Research and Future Trend

Edited by: J Marxsen (2016)

www.caister.com/climate

- Biofilms in Bioremediation: Current Research and Emerging Technologies

Edited by: G Lear (2016)

www.caister.com/biorem

- Microalgae: Current Research and Applications Edited by: MN Tsaloglou (2016) www.caister.com/microalgae

- Gas Plasma Sterilization in Microbiology: Theory, Applications, Pitfalls and New Perspectives Edited by: H Shintani, A Sakudo (2016) www.caister.com/gasplasma

- Virus Evolution: Current Research and Future Directions Edited by: SC Weaver, M Denison, M Roossinck, et al. (2016) www.caister.com/virusevol

- Arboviruses: Molecular Biology, Evolution and Control Edited by: N Vasilakis, DJ Gubler (2016) www.caister.com/arbo

- Shigella: Molecular and Cellular Biology Edited by: WD Picking, WL Picking (2016) www.caister.com/shigella

-Aquatic Biofilms: Ecology, Water Quality and Wastewater Treatment

Edited by: AM Romaní, H Guasch, MD Balaguer (2016)

www.caister.com/aquaticbiofilms

- Alphaviruses: Current Biology

Edited by: S Mahalingam, L Herrero, B Herring (2016)

www.caister.com/alpha

- Thermophilic Microorganisms

Edited by: F Li (2015)

www.caister.com/thermophile
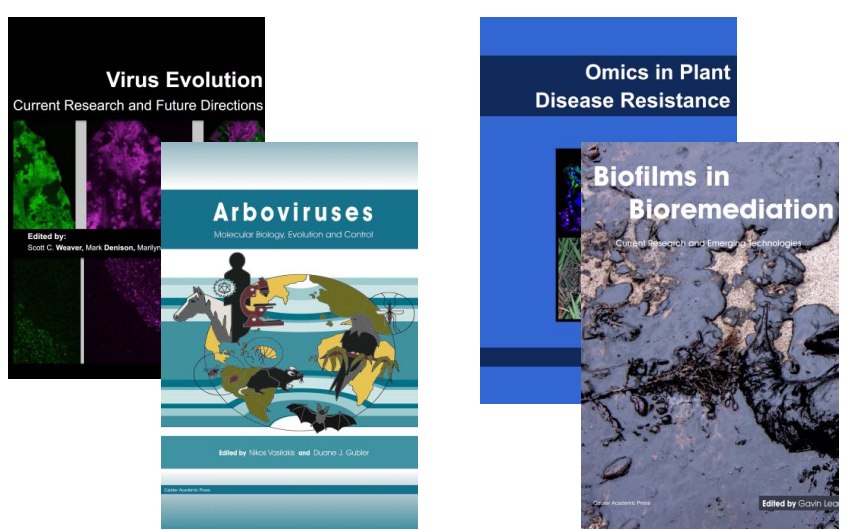
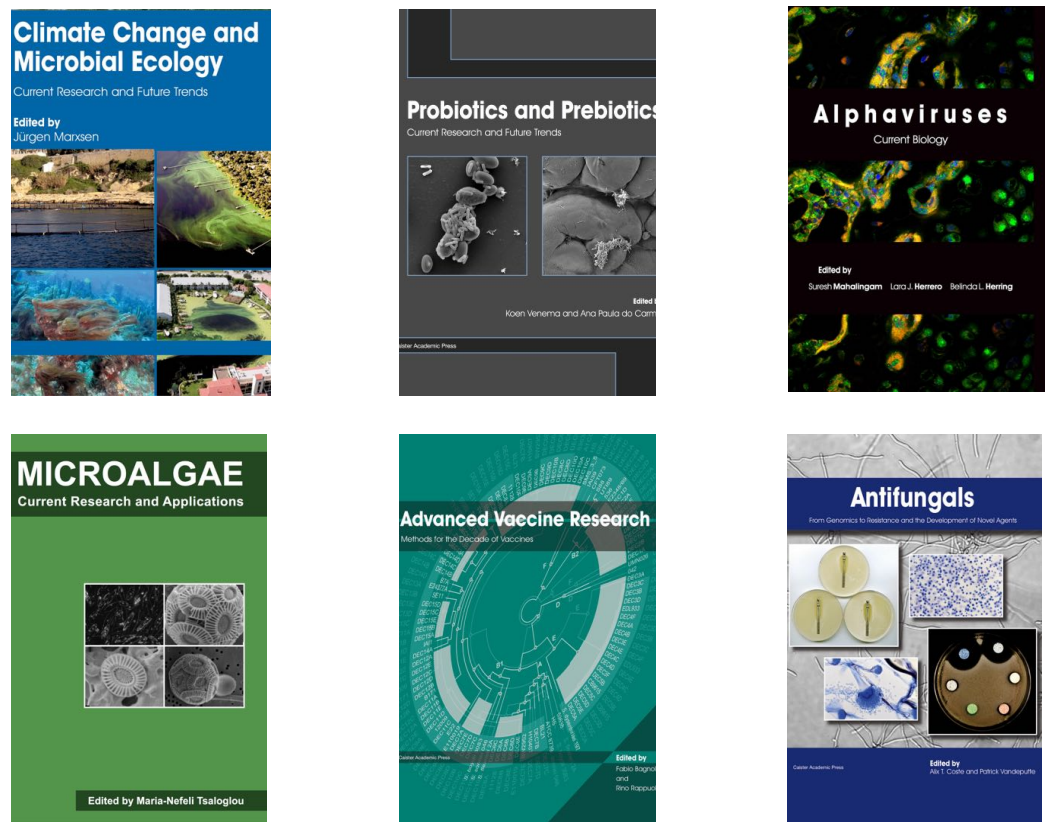

- Flow Cytometry in Microbiology: Technology and Applications Edited by: MG Wilkinson (2015) www.caister.com/flow

- Probiotics and Prebiotics: Current Research and Future Trends Edited by: K Venema, AP Carmo (2015) www.caister.com/probiotics

- Epigenetics: Current Research and Emerging Trends Edited by: BP Chadwick (2015) www.caister.com/epigenetics2015

- Corynebacterium glutamicum: From Systems Biology to Biotechnological Applications

Edited by: A Burkovski (2015)

www.caister.com/cory2

- Advanced Vaccine Research Methods for the Decade of Vaccines

Edited by: F Bagnoli, R Rappuoli (2015)

www.caister.com/vaccines

- Antifungals: From Genomics to Resistance and the Development of Novel Agents

Edited by: AT Coste, P Vandeputte (2015)

www.caister.com/antifungals

- Bacteria-Plant Interactions: Advanced Research and Future Trends Edited by: J Murillo, BA Vinatzer, RW Jackson, et al. (2015) www.caister.com/bacteria-plant

\section{- Aeromonas}

Edited by: J Graf (2015)

www.caister.com/aeromonas

- Antibiotics: Current Innovations and Future Trends

Edited by: S Sánchez, AL Demain (2015)

www.caister.com/antibiotics

- Leishmania: Current Biology and Contro Edited by: S Adak, R Datta (2015) www.caister.com/leish2

- Acanthamoeba: Biology and Pathogenesis (2nd edition) Author: NA Khan (2015)

www.caister.com/acanthamoeba2

- Microarrays: Current Technology, Innovations and Applications Edited by: Z He (2014)

www.caister.com/microarrays2

- Metagenomics of the Microbial Nitrogen Cycle: Theory, Methods and Applications

Edited by: D Marco (2014)

www.caister.com/n2 